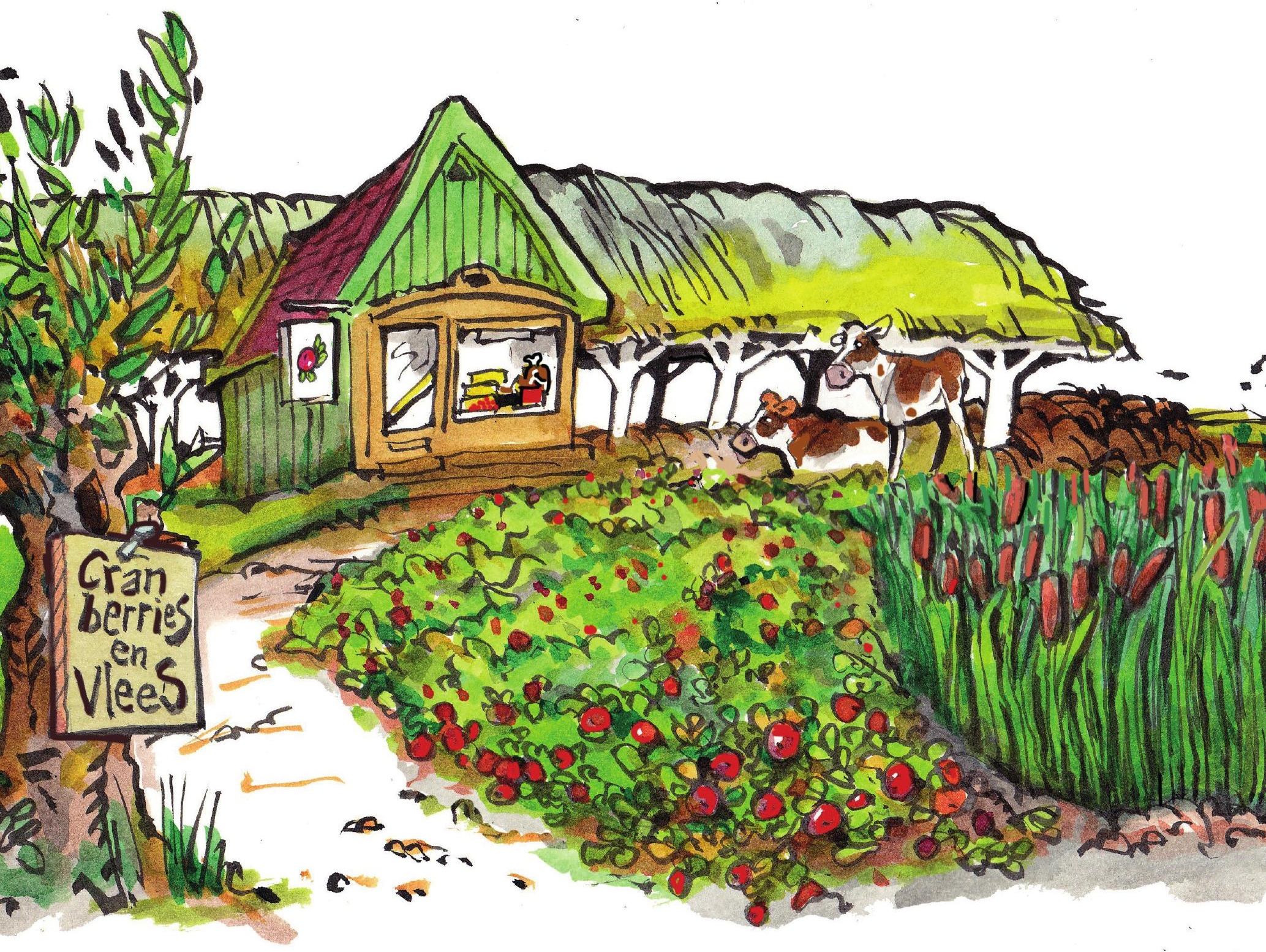

Naar klimaatbestendige agrarische bedrijven op veen en moerige gronden in de Veenkoloniën

Daan Verstand, Ellen Bulten \& Marcel Vijn 


\title{
Naar klimaatbestendige agrarische bedrijven op veen en moerige gronden in de Veenkoloniën
}

\author{
Daan Verstand \\ Ellen Bulten
}

Marcel Vijn

Dit onderzoek is in opdracht van het ministerie van Landbouw, Natuur en Voedselkwaliteit uitgevoerd door de Stichting Wageningen Research (WR), business unit Open Teelten, in het kader van het Kennis Basis programma Circular and Climate Neutral Society.

WR is een onderdeel van Wageningen University \& Research, samenwerkingsverband tussen Wageningen University en de Stichting Wageningen Research.

Wageningen, februari 2020 
Verstand, D., Bulten, E., Vijn, M., 2019. Naar klimaatbestendige agrarische bedrijven op veen en moerige gronden in de Veenkoloniën. Wageningen Research, Rapport WPR 825.

Dit rapport is gratis te downloaden op https://doi.org/10.18174/515384

Met dank aan Jan van de Akker, Gerard Hoekzema, Johan Specken, Marjoleine Hanegraaf, Janjo de Haan en Wilfried Heijnen voor het enthousiast meedenken, en Henk van Ruitenbeek voor het in beeld brengen van de varianten door tekeningen te schetsen.

Trefwoorden: Veengronden, moerige gronden, broeikasgasemissie, boerderijen, maatregelen.

(C) 2019 Wageningen, Stichting Wageningen Research, Wageningen Plant Research (WPR), Business unit Open Teelten, Postbus 430, 8200 AK Lelystad; www.wur.nl/plant-research.

KvK: 09098104 te Arnhem

VAT NL no. 8113.83.696.B07

Stichting Wageningen Research. Alle rechten voorbehouden. Niets uit deze uitgave mag worden verveelvoudigd, opgeslagen in een geautomatiseerd gegevensbestand, of openbaar gemaakt, in enige vorm of op enige wijze, hetzij elektronisch, mechanisch, door fotokopieën, opnamen of enige andere manier zonder voorafgaande schriftelijke toestemming van Stichting Wageningen Research.

Stichting Wageningen Research is niet aansprakelijk voor eventuele schadelijke gevolgen die kunnen ontstaan bij gebruik van gegevens uit deze uitgave.

Rapport WPR 825

Tekening omslag: Henk van Ruitenbeek 


\section{Inhoud}

$\begin{array}{ll}\text { Samenvatting } & 5\end{array}$

$1 \quad$ Introductie $\quad 6$

$\begin{array}{lll}1.1 & \text { Aanleiding en context } & 6\end{array}$

1.2 Focus regio $\quad 6$

1.3 Achtergrond informatie - $\mathrm{CO}_{2}$ emissie en bodemdaling 7

1.4 Gevolgen van veenoxidatie $\quad 8$

$2 \quad$ Aanpak $r 11$

$\begin{array}{lll}2.1 & \text { Literatuur onderzoek } & 11\end{array}$

2.2 Interactief proces $\quad 11$

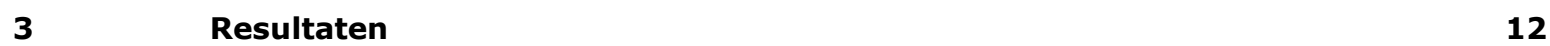

3.1 Maatregelen uit literatuur $\quad 12$

3.1.1 Waterpeil - compartimentering $\quad 12$

3.1.2 Natte teelten 13

$\begin{array}{ll}3.1 .3 \text { Infiltratiedrains } & 14\end{array}$

3.1.4 Onderwerken van veen 16

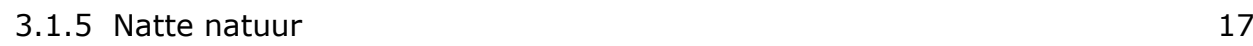

$\begin{array}{ll}3.1 .6 \text { Grasland } & 18\end{array}$

3.2 Interactief proces $\quad 18$

3.2.1 Stakeholderanalyse 18

$\begin{array}{ll}3.2 .2 \text { Varianten en scoring } & 21\end{array}$

4 Discussie $r$

4.1 Aanpak 29

4.2 Resultaten $\quad 29$

4.2.1 Toepasbaarheid maatregelen literatuur $\quad 29$

4.2.2 Boerderij varianten $\quad 30$

$\begin{array}{ll}4.2 .3 \text { Synthese } & 30\end{array}$

$5 \quad$ Conclusie en aanbevelingen $\quad 32$

$6 \quad$ Literaturur $\quad 33$

Bijlage $1 \quad$ Experts aanwezig bij de werksessie $\quad 34$

Bijlage 2 Werkplan 2020 


\section{Samenvatting}

Landbouwkundig gebruik van veen en moerige gronden leidt tot de uitstoot van broeikasgassen doordat veen oxideert. Dat gebeurt als de veenpakketten boven de grondwaterstand liggen. Tezamen stoten veen en moerige gronden in Nederland rond de zes megaton $\mathrm{CO}_{2}$ equivalenten per jaar uit. Binnen het Klimaatakkoord hebben alle sectoren, ook de landbouw, een opgave toegekend gekregen om een emissiereductie te realiseren. Veen en moerige gronden hebben de opgave om vanaf 2030 één megaton $\mathrm{CO}_{2}$ equivalenten minder uit te stoten per jaar.

Dit rapport focust zich op mogelijkheden om bij te dragen aan de emissiereductie doelstelling van veen en moerige gronden die akkerbouwmatig gebruikt worden. Hierbij wordt er gefocust op de Veenkoloniën, waar veenpakketten in variabele diktes voorkomen en akkerbouw het gangbare landgebruik is, met bijbehorende grote ontwateringsdiepte. Dat leidt op plekken waar veel veen voorkomt tot een flinke bodemdaling van 1 a $2 \mathrm{~cm}$ per jaar. Dat resulteert in toenemende hoogteverschillen binnen percelen; de zandkoppen dalen niet mee, en de veenputten dalen juist steeds meer. Dit veroorzaakt droogte schade aan gewassen in droge tijden op de hoge plekken, en natschade in de lage plekken tijdens natte periodes. Het waterschap staat voor de beslissing voor de inrichting van het toekomstig watersysteem. Blijft akkerbouwmatig landgebruik, met bijbehorende lage waterstanden mogelijk? Of kunnen er andere vormen van landbouw plaatsvinden, waardoor er geen grote investeringen in het watersysteem gedaan hoeven te worden. Dit onderzoek draagt bij aan deze discussie.

$\mathrm{Er}$ is in literatuur onderzoek gedaan naar maatregelen die de $\mathrm{CO}_{2}$ emissies van veengronden kunnen reduceren. Maatregelen zoals het onderwerken van veen en infiltratiedrainage zouden het huidige akkerbouw systeem in stand kunnen houden en tegelijkertijd een reductie van emissies realiseren. $\mathrm{Er}$ zijn ook maatregelen gevonden waarbij de functie akkerbouw wordt gewijzigd naar grasland, natte teelten of natte natuurgebieden. Voor dikke veenpakketten in lage plekken van de Veenkoloniën zijn natte teelten en natte natuur een goede oplossing. Bij de dunnere veengronden en moerige gronden kan het onderwerken van veen tot onder de grondwaterspiegel een oplossing zijn.

De maatregelen zijn gecombineerd in een zestal ontworpen boerderij-varianten, elk met een specifieke focus. Deze zes zijn; internetboerderij, circulaire boerderij, koolstofboerderij, recreatieboerderij, veenproductenboerderij en de water- en energieboerderij. Zo biedt de internetboerderij technische oplossingen om het huidige systeem beter en fijnmaziger in te richten met infiltratiedrainage, terwijl de veeproductenboerderij zich op natte teelten als cranberries en lisdodde richt. Alle varianten zijn door experts gescoord op een aantal milieukundige en sociaal economische factoren, met een diffuus beeld als resultaat; de ene variant scoort erg goed op een reductie van emissies (de koolstofboerderij), terwijl de andere bijdraagt aan de verdiensten van de landbouw (internet boerderij). Helder is dat het gebied om maatwerk vraagt en er niet één maatregel of boerderij variant is die in het hele focus gebied toegepast kan worden. Dat komt mede door de variatie aan veendikte in ruimtelijke zin en omdat de boerderijvarianten nichemarkten aan zullen moeten boren. In het vervolgonderzoek wordt hier samen met belanghebbende verder naar gekeken. 
Binnen het Kennis Basis Programma Circular and Climate Neutral Society van Wageningen Research wordt gekeken naar hoe de veengronden in Nederland duurzaam kunnen worden gebruikt, met het oog op een reductie van broeikasgasemissies en circulariteit. Dit rapport richt zich op het reduceren van broeikasgasemissies van veen en moerige gronden die akkerbouwmatig gebruikt worden.

We spreken van een veengrond als: het bodemprofiel tot $80 \mathrm{~cm}$ diepte voor meer dan de helft uit organisch materiaal bestaat (NHI, 2008). De bodem wordt geclassificeerd als moerige grond als er een 10 à $40 \mathrm{~cm}$ dikke organische laag voor komt die binnen $40 \mathrm{~cm}$ onder het maaiveld begint (NHI, 2008).

\subsection{Aanleiding en context}

Veen en moerige gronden maken een groot deel uit van de Nederlandse bodems. De bodemkaart 2018 geeft aan dat het areaal veengronden 267800 hectare is, en het areaal moerige gronden 168400 hectare (WUR, 2018). De broeikasgasemissie van veenbodems bedraagt momenteel ongeveer 4.25 megaton $\mathrm{CO}_{2}$ equivalenten per jaar (van den Akker et al., 2010). De moerige gronden emitteren ongeveer 2 megaton $\mathrm{CO}_{2}$ equivalenten per jaar (van den Akker 2019, persoonlijke communicatie). In 2030, zo is gesteld in het klimaatakkoord, een reductie van 1 megaton $\mathrm{CO}_{2}$ equivalenten emissie per jaar van de veen en moerige gronden tezamen gerealiseerd zijn (PBL, 2018).

Volgens de federatie Natuur en Milieu in Zuid-Holland, staat de uitstoot van broeikasgassen door veenoxidatie in Nederland gelijk met 25 procent van de totale uitstoot aan broeikasgassen door auto's op de Nederlandse wegen (Dagblad van het Noorden, 2019). Bovendien wordt een klein deel van de stikstof die mineraliseert bij veen oxidatie omgezet in het krachtige broeikasgas $\mathrm{N}_{2} \mathrm{O}$ (lachgas), waardoor de emissie uitgedrukt in $\mathrm{CO}_{2}$-equivalent met circa $12 \%$ toeneemt (Kuikman, Van Den Akker, \& De Vries, 2005). Emissie van broeikasgassen wordt in dit rapport uitgedrukt in $\mathrm{CO}_{2}$-equivalenten, wat kan bestaan uit koolstofdioxide $\mathrm{CO}_{2}$, methaan $\mathrm{CH}_{4}$ en lachgas $\mathrm{N}_{2} \mathrm{O}$.

Een bijkomend verschijnsel van de emissie van broeikasgasemissie door veenoxidatie, is bodemdaling. Het Rijk roept ook om actie om bodemdaling en broeikasgasemissies van veenoxidatie te reduceren (Rijkswaterstaat, 2017). Daarnaast komen er bij de oxidatie van veen nutriënten vrij. Gezien de ontwikkeling richting kringlooplandbouw is dat niet gewenst. De nutriënten die vrijkomen, worden niet allemaal benut door de landbouwgewassen en spoelen uit, met nadelige gevolgen voor de waterkwaliteit (van den Akker 2019, persoonlijke communicatie).

Dit project brengt maatregelen in kaart en identificeert varianten voor alternatief beheer van veen en moerige gronden met akkerbouwmatig grondgebruik, om de gestelde emissiereductiedoelstelling te behalen. Daartoe zijn twee onderdelen uitgewerkt: Ten eerste een literatuurstudie waarin is uitgewerkt welke maatregelen er beschikbaar zijn voor akkerbouw op veen en moerige gronden, en ten tweede zijn in samenwerking met experts concrete boerderij varianten uitgewerkt voor akkerbouw op veen en moerige gronden.

\subsection{Focus regio}

De focus in dit rapport is op veen of moerige gronden waar akkerbouw op wordt bedreven. Hierbij zijn de Veenkoloniën een casus waarin dit nader wordt bestudeerd. In Drenthe is momenteel ongeveer 20.000 hectare akkerbouw op veengronden aanwezig (de Vries, Hendriks, Kemmers, \& Wolleswinkel, 2008). Op deze akkerbouwgronden in de Veenkoloniën vindt ontwatering plaats door zogenoemde wijken en kanalen, waardoor zuurstof in contact komt met het veen in de bodem. Dat resulteert in de afbraak van het veen, wat weer leidt tot emissie van broeikasgassen en bodemdaling. De grondwaterstand ligt op veel percelen meer dan 1 meter ontwateringsdiepte onder het maaiveld 
(Waterschap Hunze en Aa's, 2017), waardoor het veen dat daarboven ligt gemakkelijk oxideert. Dit lage waterpeil is een vereiste voor de akkerbouwmatige teelten. Doordat de bodem daalt als gevolg van veenoxidatie en akkerbouwmatig landgebruik blijft bestaan, zal het waterpeil verlaagt moeten worden om te resulteren in rendabele akkerbouw. Maar dat leidt op zijn beurt weer in een verder gaande veenoxidatie en broeikasgasemissie.

Het waterschap Hunze en Aa's werkt als waterbeheerder aan deze problematiek en zoekt oplossingen om de neerwaartse spiraal (veen oxidatie -> bodemdaling -> peilverlaging vanwege te natte omstandigheden -> veen oxidatie -> bodemdaling) om te keren. Ze hebben daarvoor in samenwerking de pilot Valthermond opgestart, om daar te kijken naar de spreiding en dikte van het veen, de gevolgen van oxidatie in kaart te brengen en over oplossingen na te denken (Waterschap Hunze en Aa's, 2017).

Figuur 1 geeft de dikte van veenpakketten in het pilotgebied aan. Wat opvalt is dat de veendiktes sterk variëren, van dikker dan anderhalve meter parallel aan de Hondsrug links onder op de kaart, tot amper $10 \mathrm{~cm}$ dik verder richting het oosten (rond Valthermond). De dikke veenplekken zijn zogenaamde veenputten.

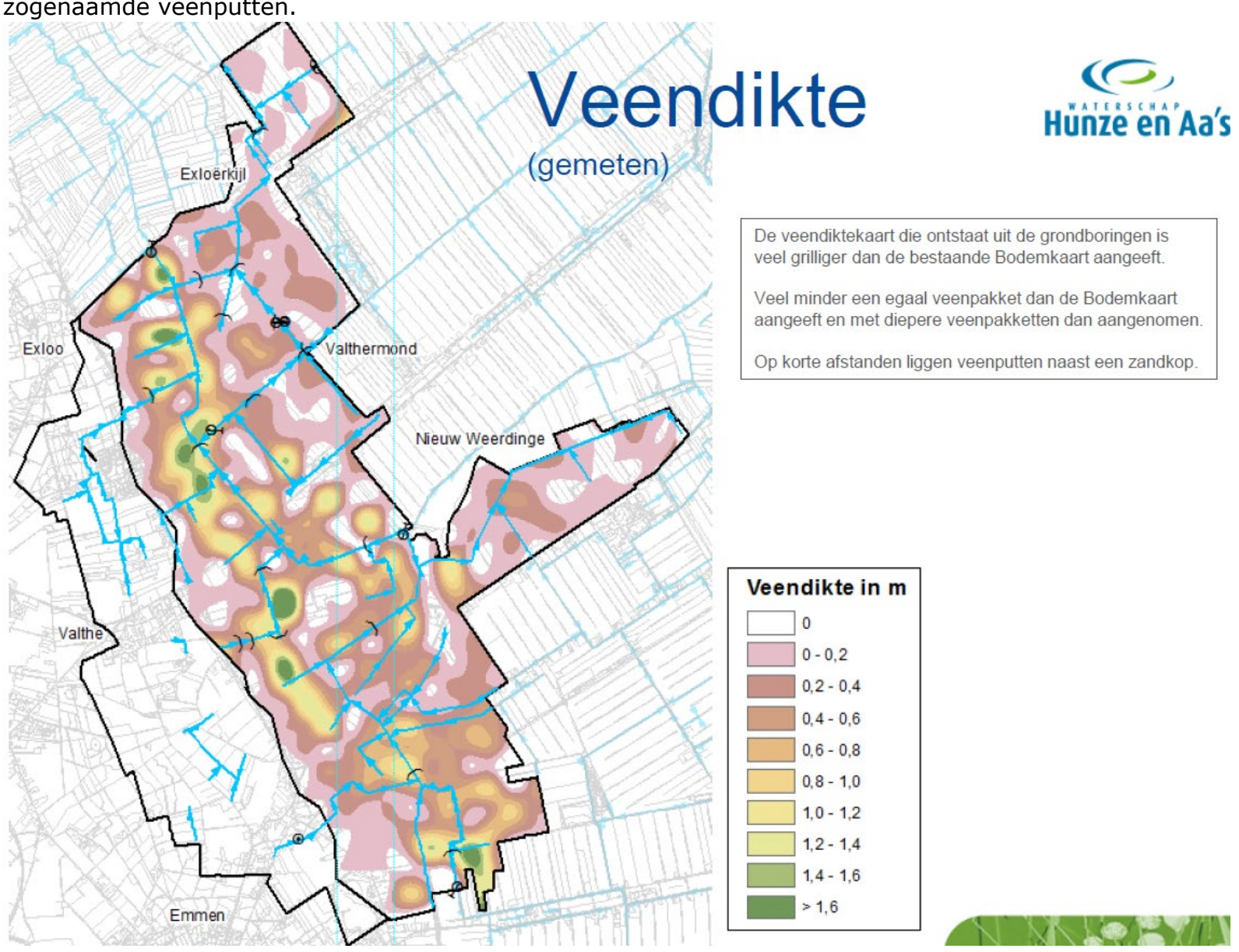

Figuur 1. Veendikte in de regio Valthermond, Drenthe (Waterschap Hunze en Aa's, 2017, kartering uit 2011).

\subsection{Achtergrond informatie $-\mathrm{CO}_{2}$ emissie en bodemdaling}

Als gevolg van veenoxidatie door lage waterstanden, daalt de bodem. Een vuistregel voor bodemdaling op veengronden is 1 á $2 \mathrm{~mm}$ bodemdaling per $10 \mathrm{~cm}$ veendikte boven de gemiddeld laagste grondwaterstand (GLG) per jaar (Waterschap Hunze en Aa's, 2017). De waterstanden in de akkerbouwgebieden in het gebied van Hunze en Aa's liggen tussen de 1,20 - 1,60 meter onder het maaiveld. Het veen ligt in het pilotgebied Valthermond vlak onder het maaiveld (Waterschap Hunze en Aa's, 2017). Dat houdt in dat er $12 \mathrm{~mm}-24 \mathrm{~mm}$ bodemdaling per jaar plaats kan vinden op plekken 
waar dikke veenlagen aanwezig zijn. Volgens het waterschap Hunze en Aa's (2017) is de bodemdaling dicht bij de Hondsrug, waar de dikke veenpakketten aanwezig zijn, rond de $20 \mathrm{~mm}$ per jaar. In de dunnere pakketten in de rest van het gebied is de bodemdaling rond de $10 \mathrm{~mm}$ per jaar.

Iedere $\mathrm{mm}$ bodemdaling leidt tot $2259 \mathrm{~kg} \mathrm{CO} 2$ uitstoot per hectare per jaar (van den Akker et al., 2010). Wordt dit doorberekend naar de geschatte bodemdaling in de Veenkoloniën (tussen de 12 en $24 \mathrm{~mm}$ per jaar), dan resulteert dat in een berekende $\mathrm{CO}_{2}$ emissies tussen $27.108 \mathrm{~kg}-54.216 \mathrm{~kg}$ per hectare per jaar. Deze $\mathrm{CO}_{2}$ uitstoot is wel afhankelijk van lokale omstandigheden, zoals bulk-density, fractie van bodemdaling als gevolg van oxidatie van organisch materiaal ten opzichte van de totale bodemdaling (zie van den Akker (2010)). De berekend inschatting ligt boven de inschatting die van den Akker (2010) voor veenweide gemaakt heeft (19 ton $\mathrm{CO}_{2}$ emissie per jaar). Dit verschil is te verklaren door de lagere grondwaterstanden op akkerbouwland ten opzichte van grasland en de intensievere grondbewerking. De Vries (2008) vermeldt dat de afbraak van veen bij akkerbouwmatig gebruik groter is dan in het veenweidegebied, als gevolg van diepere grondwaterstanden en intensievere grondbewerking, resulterend in 25ton $\mathrm{CO}_{2}$ eq emissie per ha per jaar op de Veenkoloniale gronden. Van de Riet (2018) schat de emissie van veenweide grasland van één hectare met $60 \mathrm{~cm}$ drooglegging van het water in de ordegrootte van 25 ton $\mathrm{CO}_{2}$ per hectare per jaar. Voor een extensief grasland wordt de emissie tussen de 6 en 14 ton $\mathrm{CO}_{2}$ eq. per ha per jaar geschat (Günther et al., 2017). De hoogste uitstoot per hectare is gevonden in een studie van de natuur en milieufederatie Groningen (2014), in een akkerbouw systeem in Exloo op veengrond, met een grondwaterstand van $140 \mathrm{~cm}$ : 72.89 ton $\mathrm{CO}_{2}$ per ha per jaar.

Er wordt verwacht dat door hogere temperaturen als gevolg van klimaatverandering de bodemdaling en dus $\mathrm{CO}_{2}$ uitstoot sterk kan worden vergroten (van den Akker et al., 2010).

\subsection{Gevolgen van veenoxidatie}

Omdat de dikte van de veenpakketten in de Veenkoloniën sterk varieert (zie Figuur 1), worden de hoogteverschillen binnen de percelen vergroot als gevolg van de oxidatie van veen. Op de plekken waar veel veen is, oxideert veel en treedt veel bodemdaling op. Op plekken waar amper veen is de zandkoppen, vindt minimale bodemdaling plaatst. Hierdoor ontstaan er binnen percelen aanzienlijke hoogteverschillen. De gevolgen hiervan zijn in Tabel 1 opgesomd door de Vries en collega's (2008). De lage plekken worden steeds natter omdat die lager komen te liggen, terwijl de hoge plekken juist droger worden. Dat heeft effect op de productie van landbouwgewassen. In natte jaren treedt schade op door verdrinking van gewassen op de lage plekken, terwijl in droge jaren schade optreedt als gevolg van watertekort op de hoge delen. Daarnaast wordt de bewerkbaarheid van de grond door te hoogteverschillen binnen het perceel gecompliceerder.

De infrastructuur en het watersysteem merken ook de gevolgen van bodemdaling en de in het verleden gehanteerde grondwaterverlagingen; wegen verzakken en duikers in het gebied komen bijna droog te staan door alsmaar lagere grondwaterstanden.

Tabel 1. De gevolgen voor de landbouw als resultaat van ongelijke bodemdaling door variaties in veendiktes (de Vries et al., 2008).

\begin{tabular}{|l|l|l|}
\hline Kenmerken & Lage delen & Hoge delen \\
\hline Bodemopbouw & Veengronden en moerige gronden & Zandgronden \\
\hline Samenstelling bouwvoor & Humusrijk tot venig zand & Humusrijk zand \\
\hline Grondwatertrap & $\begin{array}{l}\text { II en III } \\
(\mathrm{GHG}<40 \mathrm{~cm} \text { en GLG }<120 \mathrm{~cm})\end{array}$ & $\begin{array}{l}\text { Vl en VI } \\
(\mathrm{GHG}>40 \mathrm{~cm} \text { en GLG }>120 \mathrm{~cm})\end{array}$ \\
\hline Doorlatendheid & Matig & Groot \\
\hline Kans op wateroverlast & Groot & Gering \\
\hline Berijdbaarheid & Gering tot matig & Groot \\
\hline Vochtleverend vermogen & Matig tot goed & Matig \\
\hline Stikstof nalevering & Groot & Gering \\
\hline
\end{tabular}


Om de lage delen droog te houden, zijn peilverlagingen doorgevoerd. Dit betekent echter wel dat de hoge delen nog droger worden en er op de lage delen weer veenoxidatie ontstaat. Zonder peilverlaging wordt echter meer dan $5 \%$ van het oppervlak gemarkeerd als 'te nat', wat niet in lijn is met de gestelde drooglegging (Waterschap Hunze en Aa's, 2017). Bij een alsmaar verdere verlaging van het waterpeil worden de hoge gronden (droge plekken) ruimtelijk gezien steeds groter. Bij het loslaten van de maximaal $5 \%$ te nat norm, hoeft het waterpeil niet verlaagd te worden. Er ontstaan dan grotere plekken die te nat zijn, maar het profiterend oppervlak kan dan ook groter worden, ten kosten van het te droge deel. Dat is het scenario 'klimaatadaptief' is in Figuur 2 illustratief weergegeven door het Waterschap Hunze en Aa's. Verder is in Figuur 2 is te zien wat er gebeurt als de peilen steeds verlaagt worden (scenario traditioneel). Het oppervlak 'te nat' blijft daardoor maximaal $5 \%$ van het gebiedsoppervlak, maar het profiterende deel neemt af ten opzichte van de te droge delen (Waterschap Hunze en Aa's, 2017).

Ons onderzoek en dit huidige rapport zoomen onder andere in op wat voor landbouw er plaats kan vinden op deze te natte stukken.

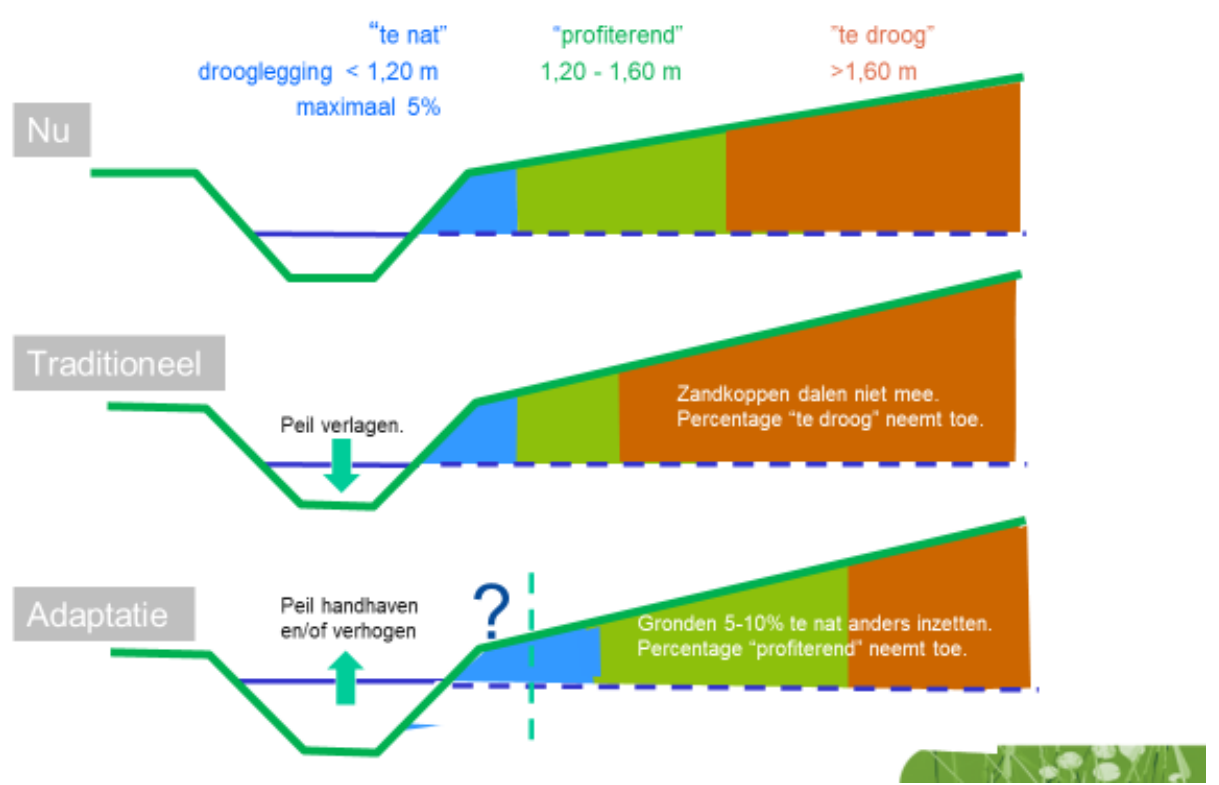

Figuur 2. Schematische weergave van de situatie waarin het waterpeil ook in de toekomst verlaagd zal worden (traditioneel), of waarin aanpassing in het huidige systeem worden gerealiseerd (adaptatie) (Waterschap Hunze en Aa's, 2017).

Een van de gevolgen van veenoxidatie is dat bodemprofielen veranderen (de Vries et al., 2008). Dat is te zien in Figuur 3 waar het veen uit het bodemprofiel verdwijnt door oxidatie, waardoor de bodem in een andere bodem-klasse valt. 


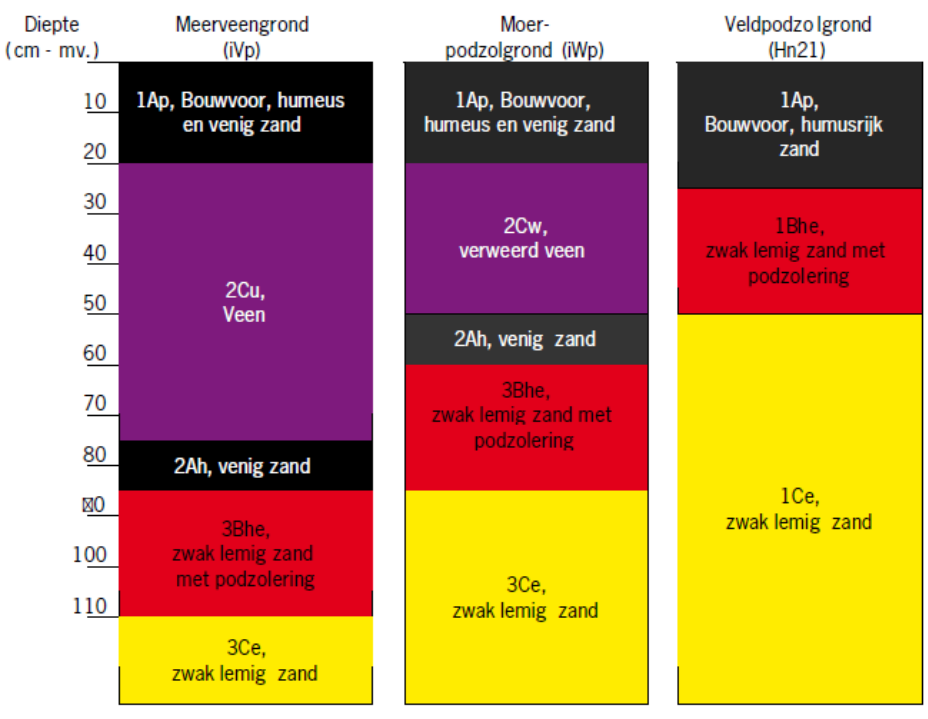

Figuur 3. Schematische weergave van de verandering van het bodemprofielen als gevolg van veenafbraak. Links het oorspronkelijke profiel en rechts na enkele decennia van veenafbraak. NB door het verdwijnen van het veen is het maaiveld t.o.v. NAP rechts ongeveer $60 \mathrm{~cm}$ gedaald.

Gezien de klimaatopgave rond de reductie van $\mathrm{CO}_{2}$ uitstoot en de problemen die bodemdaling met zich meebrengt, moet er gekeken worden naar oplossingen. Het lijkt erop dat de huidige aanpak waar het waterpeil steeds verlaagd wordt niet meer geschikt is. Akkerbouwmatig landgebruik heeft dat lagere peil echter wel nodig om nat schade te voorkomen. Zeker gezien de zeer plaatselijk variërende veendikte zal maatwerk nodig zijn.

Dit rapport beschrijft reeds onderzochte opties ter reductie van $\mathrm{CO}_{2}$ uitstoot en verkent een aantal varianten die boer en gebied perspectief kunnen bieden. 


\section{Aanpak}

\section{$2.1 \quad$ Literatuur onderzoek}

Om tot een overzicht te komen van de situatie en mogelijke maatregelen om emissie van veen en moerige gronden te reduceren, is een inventarisatie gedaan in de literatuur. Eerst is de huidige situatie omtrent de uitstoot van veen en moerige gronden en de emissiereductie eisen vanuit het Klimaatakkoord uitgezocht. De situatie in het focus gebied, de Veenkoloniën, is verkend om een idee te krijgen van lokale opgaven. Vervolgens zijn relevante rapporten en wetenschappelijke artikelen geraadpleegd en benut om een indruk te krijgen van de mate waarin maatregelen bij kunnen dragen aan de gestelde doelen. Daarin wordt breder gekeken dan enkel maatregelen binnen de akkerbouw. Dat kunnen ook rapporten of onderzoeken zijn uit andere gebieden, zoals de veenweidegebieden. Tevens zijn gesprekken met experts gevoerd om maatregelen in kaart te brengen en de effectiviteit te identificeren.

\subsection{Interactief proces}

Aanvullend op het literatuuronderzoek is middels een gebiedsbezoek onder leiding van een regio onderzoeker van WUR Valthermond meer inzicht verkregen in de vraagstukken rond klimaatbestendige landbouw in de Veenkoloniën. Daarnaast vond op 2 oktober 2019 een expertbijeenkomst plaats waarbij 4 onderzoekers (op het gebied van o.a. veengronden, bodembeheer, akkerbouw in de regio Veenkoloniën) en een beleidsmedewerker van het Waterschap Hunze en Aa's aanwezig waren (zie bijlage 1 met lijst van experts). Het doel van de expertbijeenkomst was het valideren en verrijken van vooraf opgestelde boerderijvarianten die passen binnen klimaatbestendige landbouw in de Veenkoloniën. Deze varianten worden verder toegelicht in 3.2.2.

De expertbijeenkomst had de volgende opzet:

- Stakeholderanalyse: om eerst een beter inzicht te krijgen in de verschillende partijen en bijbehorende belangen rond akkerbouw op veen en moerige gronden in de Veenkoloniën, is samen met de experts een stakeholderanalyse gemaakt aan de hand van een invloed/belang matrix.

- Presenteren mogelijke varianten voor klimaatbestendige akkerbouwbedrijven op veengrond. Gebaseerd op literatuuronderzoek werden 5 varianten van akkerbouwbedrijven op veengronden in de Veenkoloniën gepresenteerd.

- Discussie: de aanwezige experts bediscussiëren de vijf varianten en voegen eventueel nieuwe varianten toe, om de varianten verder kleur te geven, specifieker te maken en de haalbaarheid te bediscussiëren.

- Scoring: nadat de varianten verder aangescherpt waren, scoorden de experts de varianten op natuur- en milieukundige aspecten en sociaaleconomische aspecten. Deze aspecten werden eerst ter plekken besproken en vervolgens bevestigd.

Hieronder volgt eerst een beschrijving van oplossingsopties die uit de literatuur naar voren komen om $\mathrm{CO}_{2}$ emissies van huidige akkerbouwgronden te reduceren. Vervolgens volgt een bespreking van de stakeholderanalyse en als laatste de verschillende varianten voor klimaatbestendige akkerbouwbedrijven op veengrond in de Veenkoloniën. 


\section{Resultaten}

De resultaten worden opgesplitst in twee onderdelen; resultaten uit literatuur en resultaten uit het interactieve proces. Het stuk literatuurstudie presenteert oplossingsrichtingen en het effect daarvan op broeikasgasemissies, noemt neveneffecten en kijkt welke vereisten voor implementatie de maatregel stelt om gerealiseerd te worden op de veen en moerige gronden waar akkerbouw op plaatsvindt. De resultaten van het interactieve proces tonen de lokale situatie en de opgestelde boerderij varianten en scoring daarvan.

\subsection{Maatregelen uit literatur}

Om de klimaatdoelstelling (reductie van $1 \mathrm{MT} \mathrm{CO}_{2}$ eq. uitstoot per jaar van veen en moerige gronden) te halen, zullen ook de $\mathrm{CO}_{2}$ emissies van veengronden waar momenteel akkerbouw plaatsvindt moeten worden gereduceerd. Daarbij is in deze inventarisatie een functiewijziging van landgebruik niet uitgesloten. Bestman (2019) presenteert dat de $\mathrm{CO}_{2}$ eq. uitstoot van veengronden het laagst zijn als de waterstand tussen de $-20 \mathrm{~cm}$ en $0 \mathrm{~cm}$ is ten opzichte van het maaiveld (Figuur 4 ). In die situatie is de emissie ongeveer 8 ton $\mathrm{CO} 2$ per hectare per jaar. Dat betekent dat er ten opzichte van de huidige situatie in de Veenkoloniën ( $>25$ ton $\mathrm{CO}_{2}$ emissie per hectare per jaar) een aanzienlijk reductie te behalen kan zijn. Het bereiken van deze lage uitstoot situatie kost wel tijd, zeker als de uitgangssituatie intensief landgebruik is. Als deze intensieve veenweidegronden uit gebruik genomen worden en ver-nat worden, kan er na 15 jaar zelfs koolstof opslag ontstaan (D. M. D. Hendriks, Van Huissteden, Dolman, \& Van Der Molen, 2007; Schrier-Uijl et al., 2014).

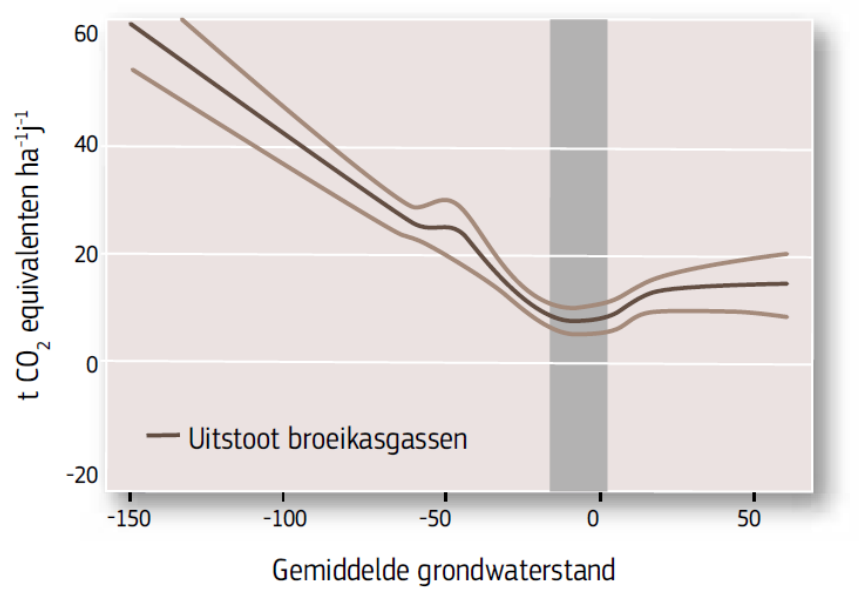

Figuur 4. Verband en $\mathbf{9 5 \%}$ betrouwbaarheidsinterval (twee bruine lijnen) tussen de grondwaterstand en de $\mathrm{CO} 2$ eq uitstoot per hectare per jaar op veengronden (Bestman et al., 2019).

Hieronder worden een aantal maatregelen gepresenteerd die deze reductie mogelijk kunnen maken. Per maatregel wordt het effect op de broeikasgasemissie voor zover mogelijk genoemd en gekwantificeerd, worden neveneffecten van de maatregel vermeld (zoals het effect op circulariteit) en wordt ingegaan op de vereisten van implementatie.

\subsubsection{Waterpeil - compartimentering}

\section{Broeikasgasemissies}

Het verhogen van het waterpeil resulteert in een verlaging van de $\mathrm{CO}_{2}$ uitstoot. Er zijn echter al flinke hoogteverschillen in het pilot gebied aanwezig, vanwege de variabele veenverspreiding. Om te zorgen 
dat er op kleine schaal een optimale waterstand gerealiseerd kan worden, is compartimentering een optie. Compartimentering maakt het mogelijk om in elk compartiment een waterpeil te realiseren dat geschikt is om $\mathrm{CO}_{2}$ emissie reductie te realiseren (van de Riet et al., 2018). Het hangt er van af hoe hoog het waterpeil wordt gezet, hoe veel $\mathrm{CO}_{2}$ emissie reductie er op kan treden (zie Figuur 4).

\section{Neveneffecten}

Dit is een gebieds-inrichtingsmaatregel. Er zal een ander landgebruik ontstaan, omdat akkerbouw een lage grondwater nodig heeft voor een optimale productie, en met compartimentering het waterpeil juist (plaatselijk) verhoogt wordt. Zie ook maatregel Natte teelten in paragraaf 3.1.2 voor deze situaties. Op plekken waar geen veen meer in de bodem is, kan akkerbouw mogelijk blijven omdat daar het waterpeil op akkerbouw-peil gezet kan worden. Het kan wel zo zijn dat perceelsgrenzen zullen moeten verschuiven, zodat per veen-dikte een compartiment gevormd kan worden voor optimaal behoud (zoals te zien is in Figuur 1).

\section{Vereisten voor implementatie}

Het verhogen van het peil in de compartimenten vereist wel dat dit water beschikbaar is in het watersysteem. Deze gebiedsmaatregel vereist samenwerking tussen boer en waterschap.

De kosten zullen aanzienlijk zijn voor onder anderen de herinrichting van het gebied, pompen, schotten/kades.

\subsubsection{Natte teelten}

\section{Broeikasgasemissies}

Natte teelten zijn gewassen die kunnen groeien in gebieden met hoge waterstanden. Het wordt ook wel paludicultuur genoemd. Er zijn verschillende gewassen die in zo een systeem passen. Bestman (2019) heeft lisdodde, riet, wilg en miscanthus met elkaar vergeleken (Tabel 2). Günther et al. (2017) heeft gekeken naar 'Sfagnum farming' als natte teelt. Dat is de productie van veenmos op natte gronden, dat geoogst wordt en toegepast wordt in bijvoorbeeld de tuinbouw.

Qua broeikasgasemissies hebben lisdodde en riet minder emissies dan wilg en miscanthus. De uitstoot van het broeikasgas methaan is bij lisdodde en riet echter hoger bij waterpeilen boven het maaiveld (Bestman et al., 2019). Deze methaan uitstoot kan tijdelijk zijn, als een transitiefase na aanplant, maar hier is nog weinig over bekend (van de Akker, persoonlijk communicatie 2019). Riet kan zelfs veengroei weer mogelijk maken, wat voor koolstofvastlegging zorgt (Bestman et al., 2019).

Günther et al. (2017) hebben onderzoek gedaan naar de broeikasgasemissies bij sfagnum mos teelt. De resultaten van de proefvelden zijn nog niet direct naar grotere schaal te vertalen, maar wijzen er wel op dat de emissies van sfagnum mos veel lager kunnen uitvallen dan die van extensief grasland, waar tussen de 6-14 ton $\mathrm{CO}_{2}$ eq. per hectare per jaar wordt uitgestoten. Günther et al. (2017) hebben een minimale methaan toename gemeten in de ontwikkelfase van de sfagnum velden.

\section{Neveneffecten}

Lisdodde en riet presteren beter dan wilg en miscanthus op de meeste criteria (zie Tabel 2). 
Tabel 2. Evaluatie van vier natte teelten. Grondwaterstand is ten opzichte van maaiveld (bij opbrengst) (Bestman et al., 2019). De opbrengst is gescoord per grondwaterstand ten opzichte van maaiveld $(+20 /+5,+20 \mathrm{~cm})$.

\begin{tabular}{|c|c|c|c|c|}
\hline & Lisdodde & Riet & Miscanthus & Wilg \\
\hline \multicolumn{5}{|l|}{ Opbrengst } \\
\hline$-20 /+5 \mathrm{~cm}$ & 0 & + & - & + \\
\hline$+20 \mathrm{~cm}$ & + & + & - & - \\
\hline \multicolumn{5}{|l|}{ Ruwvoer } \\
\hline Als ruwvoer & 0 & - & - & + \\
\hline Als structuurvoer & + & + & + & - \\
\hline Absorptie voor strooisel & + & 0 & 0 & $\therefore$ \\
\hline Verbrandingswaarde & + & + & + & + \\
\hline Isolatiewaarde & $+*$ & + & 0 & + \\
\hline \multicolumn{5}{|l|}{ Diensten } \\
\hline Broeikasgassen & + & + & $-\cdots$ & $0^{\cdots *}$ \\
\hline Waterzuivering & + & + & $-\cdots$ & $-\cdots$ \\
\hline Waterberging & + & + & - & 0 \\
\hline Uitmijnen & + & 0 & $-\cdots$ & $-\cdots$ \\
\hline $\begin{array}{l}\text { Biodiversiteit en } \\
\text { landschap }\end{array}$ & + & + & - (Exoot) & 0 \\
\hline
\end{tabular}

- Wel als houtsnippers in vrijloopstal.

- Op basis van waarden die bekend zijn van kleine lisdodde.

... Evaluatie bij hoog water, bij een lager waterpeil kan dit anders zijn.

\section{Vereisten voor implementatie}

Gewassen in de paludicultuur zijn relatief nieuw in de teelt en de afzet daarvan. Boeren moeten kennismaken met de gewassen en de teelt in de vingers krijgen. Daarnaast moet er een afzetmarkt beschikbaar zijn. De rentabiliteit wordt nu voor een aantal gewassen onderzocht op boerderij Zegveld (van den Akker 2019, persoonlijke communicatie). Het sfagnum mos is relatief nieuw en kan gebruik worden als vervanging voor veen dat in tuinbouw en potgrond gebruikt wordt (Günther et al., 2017). Paludicultuur vraagt om hoge waterstanden. Dat moet gerealiseerd kunnen worden in het water systeem en het water moet beschikbaar zijn.

\subsubsection{Infiltratiedrains}

\section{Broeikasgasemissies}

Met infiltratie van water via infiltratiedrains kan een peilverhoging gerealiseerd worden, wat de veenoxidatie kan reduceren en de landbouwfunctie in stand kan blijven, (zie Figuur 5 voor een schematisch weergave van het principe). In veenweidegebieden wordt hier al uitgebreid mee geëxperimenteerd, zoals bij het Kennis Transfer Centrum Zegveld (KTC Zegveld, n.d.) en het Veenweide Innovatie Centrum (Veenweiden Innovatiecentrum, n.d.). De drains liggen minimaal $20 \mathrm{~cm}$ onder het slootpeil. In droge perioden worden de drains gebruikt om water aan te voeren, in natte periodes om water af te voeren. Zo blijft het veen natter, wat leidt tot minder vertering door oxidatie. Hoe hoger het waterpeil dat door de drains gerealiseerd wordt, des te lager de veenoxidatie, maar hoe minder goed de huidige, intensieve landbouw daar kan presteren (Natuur en Milieufederatie Groningen, 2014).

De Natuur en Milieufederatie Groningen (2014) presenteert in hun rapport Valuta voor Veen $\mathrm{CO}_{2}$ reducties van 41.65 ton per ha $\mathrm{CO}_{2}$ uitstoot door onderwaterdrainage in hun landbouwscenario in Exloo. De oorspronkelijke emissie van de akkerbouw op veen aldaar is rond de 70 ton $\mathrm{CO}_{2}$ eq. per jaar. In het landbouwscenario blijft de landbouw productief.

Het Stowa presenteert in de Deltafact onderwaterdrainage een aanzienlijk lagere maaivelddaling daling na de implementatie van onderwaterdrainage (van $3.3 \mathrm{~mm}$ per jaar naar $0.5 \mathrm{~mm}$ per jaar) (R. 
Hendriks \& van den Akker, 2018).

Deltares (Rozemeijer, Hunze, Klomp, Hunze, \& Ball, 2016) heeft onderzoek gedaan naar de mogelijkheid om met regelbare drainage de natuur en landbouw doelen (hoog water in natuur, lager in landbouw) in Drenthe te dienen. Regelbare drainage wordt gebruikt om de uitstroom van water te beperken (door in een put de uitstoomhoogte omhoog te halen). Zo wordt water bewaard voor drogere perioden. Er wordt bij regelbare drainage geen water geïnfiltreerd (van den Akker 2019 persoonlijke communicatie). In een pilot in het Achterste Diep in Drenthe zijn deze drains onderzocht. De drains waren echter snel verstopt (te hoge intreeweerstand), waardoor de werking niet optimaal was en de gewenste waterstanden niet gerealiseerd konden worden. In droge periodes werkte het systeem enigszins om veen afbraak te verminderen, maar het gewenste hoge peil kon niet worden bereikt. Andersom, in natte periodes, konden de drains niet al het water afvoeren, waardoor de gewassen nat-schade ervoeren. Daarom werd er gewerkt met een veiligheidsmarge wat betreft waterpeil; het waterpeil werd lager gehouden dan gewenst voor veenoxidatie-preventie, om zo gewasschade na een bui te voorkomen.

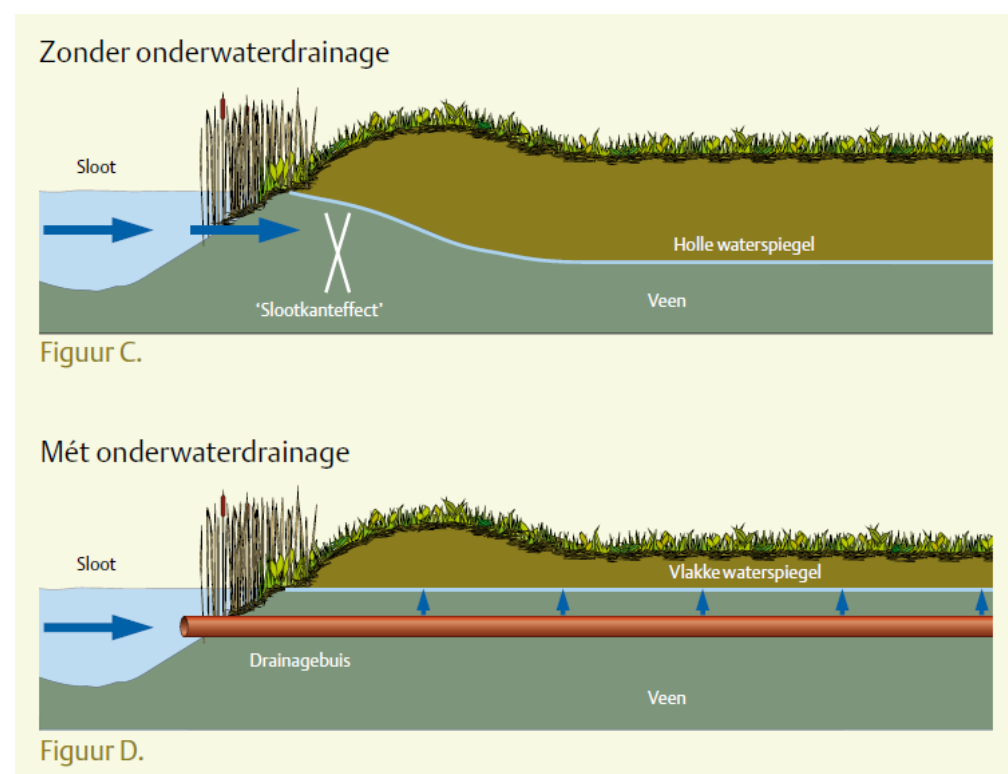

Figuur 5. Schematische weergave van de waterstanden met, en zonder onderwaterdrains (bron: (Natuur en Milieufederatie Groningen, 2014)

\section{Neveneffecten}

De waterkwaliteit kan verbeteren bij de implementatie van infiltratiedrains, omdat bij veenoxidatie nutriënten vrijkomen (Rozemeijer et al., 2016). Bij een goed werkend drainage systeem zou infiltratiedrainage kunnen leiden tot een vermindering van de nutriëntenuitspoeling als gevolg van verminderde veenoxidatie.

\section{Vereisten voor implementatie}

Helder is dat de infiltratiedrains goed moeten werken om tot het gewenste peil en effect te komen. In de proef in het Achterste diep had het system hinder van de verminderde werking van de drains, wat mogelijk veroorzaakt is door verstopping met silt, organische deeltjes en ijzeroxide. Natuur en Milieufederatie Grondingen (2014) rapporteert niet over deze problematiek.

Verder brengen deze systemen aanzienlijke kosten met zich mee tijdens implementatie (onderwater drainage: 1800 euro per ha in Zegveld (Natuur en Milieufederatie Groningen, 2014)). Voor de meest geavanceerde en nog experimentele versie van onderwaterdrainage (OWD 3.0), waarbij slootpeil en grondwaterpeil ontkoppeld worden en de grondwaterpeil beter en per perceel gestuurd kan worden, zijn de aanleg kosten $€ 2800$ per hectare (WUR, 2016). De Deltafact Onderwaterdrainage schat de kosten in tussen de 1700-2500 euro. De geschatte levensduur is 30 jaar (Hendriks \& van den Akker, 2018). 


\section{Broeikasgasemissies}

Het onderwerken van veen, door het te bedekken met mineraal materiaal (Figuur 6) of door het bodemprofiel om te keren, kan veenoxidatie reduceren. Een vereiste daarbij is wel dat het veen zo diep komt te liggen dat het onder de grondwaterstand komt, zodat de oxidatie vermindert. In het verleden is veel onderzoek verricht naar profielverbeteringen, waarin door middel van diepploegen of mengwoelen veen gemixt wordt met zand of klei. Het doel hiervan is verbeteren van het profiel door veen en minerale grond te mengen en harde lagen te verbreken.

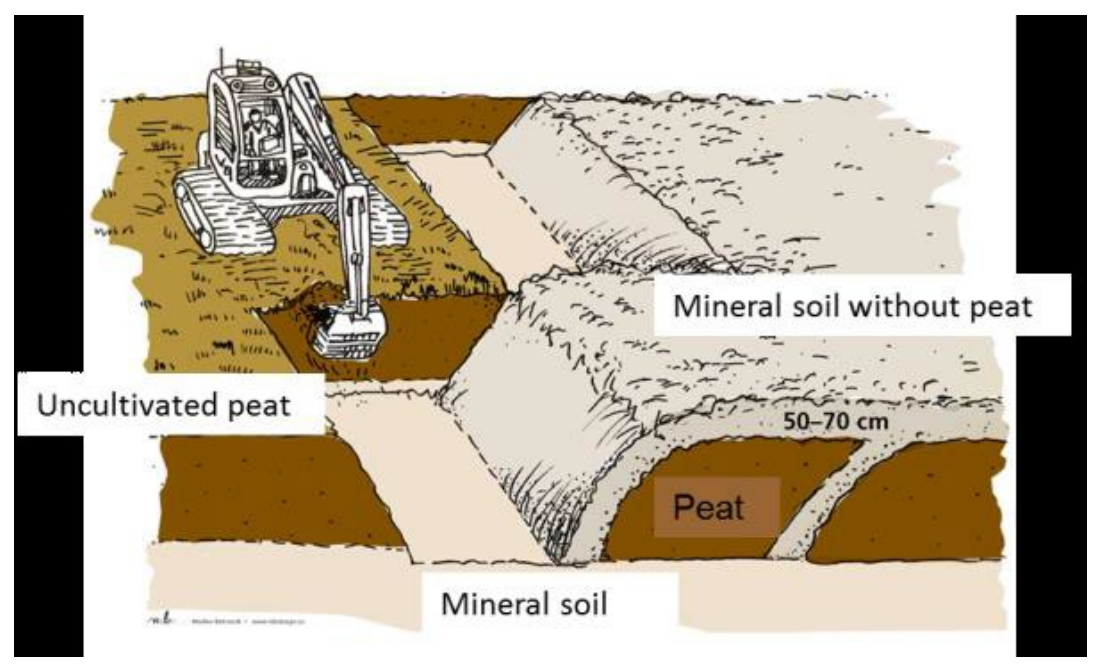

Figuur 6. Het principe van het bedekken van veen met minerale bodem (Hansen et al., 2016)

Vaak leidt dit tot een verhoogd gewasopbrengst (Havinga \& Perdok, 1968; Richardson, Dyer, \& Jewell, 1991) doordat de wortels van de gewassen dieper kunnen wortelen waardoor de droogtebestendigheid toeneemt en de waterinfiltratie verbeterd wordt (Schothorst \& Beuving, 1968). Daarnaast nemen het waterbergend vermogen het vasthouden van nutriënten door de organische stof in de ondergrond toe. De grond krijgt als het ware meer de eigenschappen van een enkeerd grond met de bijbehorende gunstige bodemkwaliteit. Deze methode is in dit opzicht dus aantrekkelijk en positief voor de landbouw, die de bodemkwaliteit ziet toenemen. Dat kan leiden tot interesse en investeringen vanuit de landbouwsector in deze oplossing. Echter, anders dan vroeger is het hoofddoel nu het conserveren van organische stof en het beperken van de $\mathrm{CO}_{2}$-emissie.

Het doel van $\mathrm{CO}_{2}$ emissie reductie gaat niet vanzelfsprekend samen met de doelen die de hierboven genoemde oudere onderzoeken presenteren (verbeteren profiel). Voor $\mathrm{CO}_{2}$ emissie reductie is het een voorwaarde dat het veen dat oorspronkelijk boven de grondwaterstand lag, door grondbewerking diep in het profiel en zoveel mogelijk onder het grondwater komt te liggen. Hansen (2016) presenteert de resultaten van het bedekken van het veenprofiel met minerale bodem dat bovenop het veen wordt geplaatst in het westen van Noorwegen (Figuur 6). Ze hebben een emissiereductie gevonden, als gevolg van het omkeren van het profiel: van 7-8 ton $\mathrm{CO}_{2}$ eq. emissie op het standaard veenprofiel naar 2-3 $\mathrm{CO}_{2}$ eq. ton per ha per jaar op het begraven profiel. Daarnaast produceert het grasland meer op het omgekeerde profiel dan op het standaardprofiel (Hansen et al., 2016). Dit goede resultaat kan waarschijnlijk nog worden verbeterd door de laag minerale grond dikker te nemen.

Richardson et al. (1991) hebben bij het mixen van de veentoplaag met de minerale ondergrond minder goede resultaten gevonden. In hun experiment in East Anglia in het Verenigd Koninkrijk, waar akkerbouwmatig gebruik wordt gemaakt van deze gronden (resulterend in een $1.84 \mathrm{~cm}$ bodemdaling per jaar in de periode 1934-1962 (Richardson et al., 1991)) is een venige toplaag gemixt met de minerale sub-laag, waardoor het veen op grotere diepte is komen te liggen. Het mixen en dieper brengen van veen heeft op een van de studie sites geleid tot een grotere hoeveelheid veen nog in de bodem. In het gemixte profiel is 20 jaar na het mixen in de diepte $0-90 \mathrm{~cm}$ nog 1151 ton veen per ha over, terwijl dat op het referentie perceel 937 ton veen per ha is (Richardson et al., 1991). Oftewel in het gemixte profiel is $22 \%$ meer veen over. 
Een derde voorbeeldkomt ui het veenweide gebied in Friesland, waar bagger is gebruikt om de bodem op te hogen en het veen dus te begraven. Dit resulteerde in een berekende reductie van $9-10$ ton $\mathrm{CO}_{2}$ per jaar (van 19 ton naar 10 ton). De beschikbaarheid van bagger en de uitstoot tijdens transport leveren wel de nodige kanttekeningen op (van den Akker, Massop, \& Rietra, 2018).

Een vierde mogelijkheid is het bezanden van het veenprofiel. In Nederland en Duitsland is dat vroeger veel gebeurd om de draagkracht te verbeteren. Het zand werd daarbij onder het ondiepe veenprofiel gehaald met zogenaamde zandvijzels. Omdat het vooral om een betere draagkracht ging, was de opgebrachte zandlaag vrij dun. Om de afbraak van het veen te verminderen zijn substantieel dikkere zandlagen nodig.

Het onderwerken van het veen (omzanden, keren van het profiel) lijkt een veelbelovende manier om snel grote hoeveelheden $\mathrm{CO}_{2}$-emissies te verminderen. De gecreëerde minerale deklaag moet daarbij zo dik zijn dat de zuurstofdoorvoer naar het veen zeer beperkt is of dat het veen onder de deklaag geheel of nagenoeg verzadigd blijft met water. Naast de dikte van de deklaag speelt dus ook de grondwaterstand een groet rol. Door een deel van het veen door de minerale deklaag te mengen, kan bovendien de bewortelingsdiepte en de bodemkwaliteit substantieel worden verbeterd wat gunstig is voor beter gewasopbrengsten en een circulaire landbouw mogelijk maakt. Daar staat tegenover dat het veen dat in de deklaag is gemengd weer deels bloot staat aan afbraak. Dit wordt wellicht min of meer gecompenseerd door aanvoer van organische stof door de diepere beworteling.

\section{Neveneffecten}

Deze maatregel is vrij ingrijpend wat betreft het bodemprofiel en de biologische activiteit. Het vraag een eenmalige investering in werkzaamheden (geschat op meer dan $€ 2000$ per hectare (persoonlijke communicatie van den Akker 2019).

\section{Vereisten voor implementatie}

Zoals eerder benoemd, (delen van) het veen moeten onder de grondwaterstand komen, om zo een reductie van oxidatie te bewerkstelligen. Gezien de diepe grondwaterstand in de Veenkoloniën (-1.20$1.60 \mathrm{~cm}$ onder maaiveld), vraagt dit zeer ingrijpende profielbewerkingen, verhoging van de grondwaterstanden en/of selectie op nattere percelen. Dit zijn vaak de percelen of plekken met veen, die wat dieper liggen en wateroverlast hebben, terwijl de hogere koppen juist verdrogen.

\subsubsection{Natte natur}

\section{Broeikasgasemissies}

Door natte natuur te realiseren, met een hoge grondwaterstand, neemt de veenoxidatie af ten opzichte van akkerbouwmatig gebruik. In het rapport Valuta voor Veen (Natuur en Milieufederatie Groningen, 2014) wordt zelfs een reductie van 66.85 ton $\mathrm{CO}_{2}$ eq. per ha per jaar gerealiseerd, ten opzichte van 72 ton emissie bij akkerbouwmatig gebruik.

In een veenweide gebied (Horstermeer) is moerasland/natte natuur gerealiseerd, met waterstanden tussen 0 en $40 \mathrm{~cm}$ onder het maaiveld. Na tien jaar vindt op deze percelen inmiddels opslag van broeikasgassen plaats, het gebied is een sink geworden van 0.86ton CO2 eq. per ha per jaar (D. M. D. Hendriks et al., 2007).

\section{Neveneffecten}

Doordat er natte natuur gemaakt wordt van landbouwgrond, vindt er geen productie meer plaats. De natte natuur kan wel bijdragen aan biodiversiteit en habitat doelstellingen.

Als het creëren van natuur op kleine schaal plaatsvindt binnen een boeren bedrijf, kan dit stuk in aanmerking komen voor de vergroeningseisen vanuit het Gemeenschappelijk Landbouw Beleid van de Europese Unie. Wellicht kan het de aantrekkelijkheid van het landschap, en bijgaande recreatie, vergroten.

Als het waterpeil omhoog gaat om deze natte natuur te realiseren, kunnen hoger gelegen akkerbouw percelen hiervan profiteren (Figuur 2).

\section{Eisen voor implementatie}

Het waterpeil moet omhoog kunnen, als er plaatselijk natte natuur gerealiseerd wordt. Dat zal in het focus gebied de laag gelegen delen zijn, waar tevens veel veen aanwezig is (de veenputten). Financiële compensatie voor de boer zijn nodig, omdat die inkomsten verliest bij de ontwikkeling van 
natte natuur. Of de grond moet gekocht worden. Vaak zullen het wel de slechte/natte percelen binnen het boeren bedrijf zijn die omgezet worden in natuur.

\subsubsection{Grasland}

\section{Broeikasgasemissies}

Grasland heeft minder last van hogere grondwaterstanden, of tijdelijke natte omstandigheden dan akkerbouwgewassen hebben (Delphy 2018). Het omzetten van akkerbouwbouwland naar grasland biedt daarnaast een lagere $\mathrm{CO}_{2}$ emissie, omdat er minder vergravingen/grondbewerking plaatsvindt en er daarnaast een hogere waterstand gehanteerd kan worden waardoor veenoxidatie wordt gereduceerd. Het PBL presenteert in de berekeningen voor het klimaatakkoord dat 9000 ha moerige gronden waar akkerbouw op plaatsvindt, goed omgezet kunnen worden in permanent grasland. Dat zou goed passen binnen de grondgebondenheid van de melkveehouderij (meer voer van eigen grond) (PBL, 2018). Het veranderen van het landgebruik van de gestelde 9000 ha zou leiden tot een 0.09 Mton $\mathrm{CO}_{2}$ emissiereductie per jaar. Permanent grasland dat extensief wordt beheerd, resulteert in weinig negatieve effecten voor de organische stof voorraad (de Vries et al., 2008). Gunther (2017) schat in dat de $\mathrm{CO}_{2}$ emissie van extensief grasland per hectare per jaar tussen de 6 en 14 ton liggen. Dat is een aanzienlijke reductie ten opzichte van de emissies bij akkerbouwmatig gebruik, waar de grondwaterstand lager is, meer grondbewerking plaatsvindt en meer vochtonttrekking optreedt door meer diep-wortelende gewassen (de Vries et al., 2008). Bij intensief beheert grasland is de inschatting dat de emissies liggen tussen 15 en 35 t CO 2 eq. per ha per jaar (bij grondwaterstanden tussen 55 en $60 \mathrm{~cm}$ onder maaiveld) (Günther et al., 2017; van de Riet et al., 2018).

Rozemeijer et al. (2016) adviseren een landgebruiksverandering om het dikke veenpakket in het beekdal van de Hunze in stand te houden; van akkerbouwland naar permanent, extensief gebruikt grasland.

\section{Neveneffecten}

De circulariteit van het lokale landbouw systeem kan verbeterd worden door gras op de juiste plekken te telen. Akkerbouw kan op de geschikte, drogere gronden, grasland op de minder geschikte natte gronden, waar veen zo behouden blijft en veevoer wordt geteeld. De akkerbouwer en de veehouder kunnen samenwerken om zo de nutriënten lokaal in het systeem te houden (mest van veehouder voor bouwland), of eventueel via grondruil (de Wolf, Klompe, Hanegraaf, Molendijk, \& Vellinga, 2018).

\section{Eisen voor implementatie}

Grasland kan geïmplementeerd worden op de natte plekken in het gebied, waar nog veel veen aanwezig is. Voor een deel vindt dit al plaats in het gebied, waar veehouders een aantal graspercelen hebben die zeker niet geschikt zijn voor akkerbouwland. Voorwaarde voor grasland is dat er wel regionaal vraag is naar het gras.

Bij extensief beheer zal de opbrengst laag zijn en zal enig vorm van compensatie plaats moeten vinden.

\subsection{Interactief proces}

Hieronder worden de resultaten van het interactieve proces met experts en belanghebbende gepresenteerd. De stakeholderanalyse brengt het krachtenveld in beeld. Vervolgens worden de boerderij-varianten gepresenteerd en besproken.

\subsubsection{Stakeholderanalyse}

$\mathrm{Bij}$ het zoeken naar oplossingen voor het tegengaan van veenoxidatie en bijbehorende problemen (e.g. bodemdaling, verslechterde waterkwaliteit, etc.), is een diverse groep actoren betrokken met uiteenlopende belangen. We hebben bijvoorbeeld te maken met boeren, het waterschap en overheidspartijen. Om stakeholders goed in kaart te brengen hebben we met behulp van experts op het gebied van veen en experts uit het Veenkoloniale gebied de een stakeholderanalyse gemaakt (Figuur 7). Hierbij maken we gebruik van een invloed/belang matrix. Belang verwijst dan naar de mate van belang die een stakeholder heeft bij het (veranderend) gebruik van veengronden voor de 
akkerbouw in Veenkoloniën. Invloed verwijst naar de macht die stakeholders hebben om verandering te bewerkstelligen en de mate waarin een stakeholder anderen kan overtuigen voor het maken van beslissingen en het volgen van bepaalde actierichtingen (DFID, 2003).

Stakeholders kunnen ingedeeld worden in drie categorieën (DFID, 2003):

1. Key stakeholders: betrokkenen die significant veel invloed (kunnen) hebben of erg belangrijk zijn voor het succes van interventies in de veenkoloniën. Hier kunnen we ook change agents typeren: zij die buitengewoon veel invloed hebben op het realiseren van verandering.

2. Primary stakeholders: actoren die direct de positieve dan wel negatieve gevolgen van een activiteit ervaren.

3. Secondary stakeholders: alle overige actoren of organisaties met een belang of intermediërende rol in een activiteit.

In de praktijk kunnen deze categorieën overlappen. Primaire of secondaire stakeholders kunnen bijvoorbeeld tegelijkertijd key stakeholder zijn.

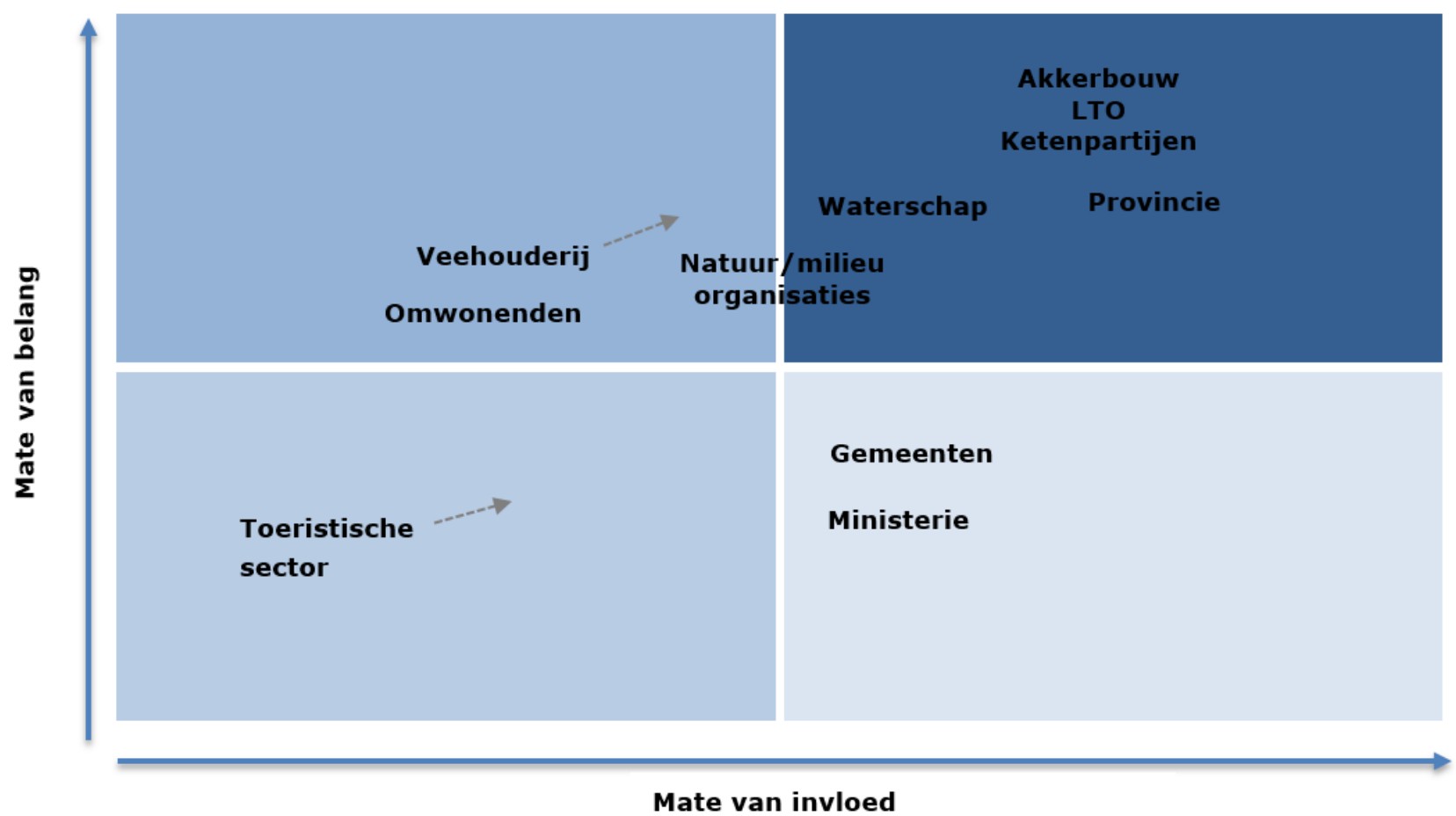

Figuur 7. Stakeholderanalyse duurzame akkerbouw in de Veenkoloniën; mate van belang versus mate van invloed.

Beginnend linksboven in de matrix worden kort alle stakeholders en hun rol in (veranderend) gebruik van veengronden voor akkerbouw in de Veenkoloniën besproken.

\section{Groot belang, weinig invloed}

Dit is een groep stakeholders die wel een groot belang heeft bij (veranderend) gebruik van veengronden voor landbouw in de Veenkoloniën, maar weinig invloed heeft op het doorvoeren van verandering. Deze stakeholders kunnen gezien worden als primaire stakeholders: zij ervaren de gevolgen van verandering, maar hebben zelf weinig invloed op het doorvoeren of tegenhouden van verandering.

\section{Veehouderij}

De veehouderij heeft weinig invloed omdat de focus ligt op akkerbouw op veen en moerige gronden. Echter, de veehouderij heeft wel belang bij gebruik van landbouwgrond in de Veenkoloniën. Zo kan het kansen bieden als er bijvoorbeeld gewerkt wordt aan nauwere samenwerkingen tussen akkerbouw en veehouderij, of als akkerbouwgrond wordt omgezet in bijvoorbeeld grasland. In oplossingsrichtingen waar akkerbouw en veehouderij intensiever gaan samenwerken of er een speciale rol voor de veehouderij is, kan de invloed als ook het belang van de veehouderij verder toenemen. 
Omwonenden in de Veenkoloniën hebben bovengemiddeld belang bij (veranderend) gebruik van veengronden door de landbouw omdat zij in hun dagelijks bestaan direct te maken krijgen met de gevolgen van veenoxidatie (met name grondverzakkingen). Omwonenden hebben echter weinig (directe) invloed op het bewerkstelligen van verandering.

\section{Natuur/milieuorganisaties}

Natuur en milieuorganisaties hebben een bovengemiddeld belang bij veranderend gebruik van veen en moerige gronden omdat zij door veranderend gebruik het vrijkomen van broeikasgassen willen tegengaan. Omdat natuur en milieuorganisaties geen directe beslissingen maken over bijvoorbeeld inrichting van het landschap of verdeling van overheidsgelden hebben zij minder invloed dan bijvoorbeeld overheids- of ketenpartijen.

\section{Groot belang, veel invloed}

Deze groep primaire stakeholders is de belangrijkste groep, de zogenaamde sleutelfiguren (key stakeholders) die zowel een groot belang hebben bij (veranderend) gebruik van veengronden voor landbouw in de Veenkoloniën als grote invloed om deze verandering door te voeren of tegen te houden. Dit is de groep stakeholders die het verschil kunnen maken.

\section{Waterschap}

Als partij die de waterstanden en het watersysteem beheert, heeft het Waterschap een groot belang en bovengemiddelde invloed op (veranderend) gebruik van veengronden in de Veenkoloniën.

\section{Akkerbouw + LTO + Ketenpartijen}

Ook de akkerbouw, LTO als belangenbehartiger van de land- en tuinbouw en verschillende ketenpartijen hebben grote invloed en een groot belang bij (veranderend) gebruik van landbouwgrond in de Veenkoloniën. Deze drie partijen beïnvloeden elkaar en zijn daarom als cluster opgenomen in de stakeholderanalyse. Akkerbouwers hebben groot belang bij ontwikkelingen in de Veenkoloniën omdat verandering van bijvoorbeeld het waterpeil directe gevolgen kan hebben op hun opbrengsten. Tegelijkertijd kunnen akkerbouwers ook invloed uitoefenen door andere gewassen te gaan telen waardoor waterpeilen naar boven of juist naar beneden moeten. Als belangenbehartiger is LTO hier ook direct bij betrokken. Echter, de ketenpartijen (e.g. afnemers) bepalen de vraag waar akkerbouwers in aanbod in dienen te voorzien. Ketenpartijen hebben dus grote invloed op gewassen die voor akkerbouwers aantrekkelijk en rendabel zijn om te telen en hebben anderzijds ook een groot belang bij goed toekomstperspectief voor akkerbouw in de Veenkoloniën.

\section{Provincie Drenthe}

De provincie Drenthe heeft veel invloed omdat de provincies eerstverantwoordelijk zijn voor het beperken van $\mathrm{CO}_{2}$ emissies van veengronden. Dit betekent ook dat de provincie aanspraak kan maken op financiering uit het klimaatakkoord voor een "klimaat gerichte aanpak veenbodems" (Zie klimaatakkoord C4 Landbouw en Landgebruik). De provincie heeft dus een groot belang omdat zij verantwoordelijk is voor het beperken van $\mathrm{CO}_{2}$ emissies en heeft tegelijkertijd veel invloed omdat de provincie als eerste bepaald waar de financiering vanuit het klimaatakkoord voor wordt gebruikt.

\section{Klein belang, veel invloed}

Deze groep stakeholders heeft wel veel invloed op het veranderproces, maar weinig (direct) belang bij verandering van de status quo. Deze secundaire stakeholders hebben het potentieel om verandering teweeg te brengen of in de weg te staan, maar zullen niet te maken krijgen met de directe gevolgen van verandering en hebben dus een klein belang.

\section{Gemeenten + ministerie $L N V$}

Als overheidspartijen hebben zowel het ministerie van Landbouw, Natuur en Voedselkwaliteit (LNV) en de gemeente minder belang maar bovengemiddelde invloed op veranderend gebruik van veen- en 
moerige gronden in de Veenkoloniën. Anders dan de provincie zijn geen van beide partijen direct verantwoordelijk voor het beperken van de $\mathrm{CO}_{2}$ emissies in de provincie. De gemeenten die onderdeel uitmaken van de veenkoloniën en provincie zijn wel verantwoordelijk voor het maken van beslissingen over zaken als bestemmingsplannen en ruimtelijke ordening.

\section{Klein belang, weinig invloed}

De stakeholders in deze groep hebben zowel een klein belang als weinig invloed op verandering. Zij staan langs de zijlijn, maar zijn indirect betrokken bij ontwikkelingen rond gebruik van veengronden door de landbouw in de Veenkoloniën.

\section{Toeristische sector}

De toeristische sector is een 'toeschouwer' met een klein belang en weinig invloed. Deze sector heeft belang bij zaken als een aantrekkelijk landschap en recreatie mogelijkheden. Veranderend gebruik van het landschap of de ontwikkeling van multifunctionele landbouw met aandacht voor recreatie creëert nieuwe kansen voor de toeristische sector waardoor in toekomstige scenario's deze sector meer invloed en belang bij het landgebruik in de Veenkoloniën kan krijgen.

\section{Synthese stakeholderanalyse}

Door middel van deze stakeholderanalyse hebben we inzicht gekregen in de verschillende belangen die stakeholders hebben bij en invloed die zij uit kunnen oefenen op interventies gericht op klimaatbestendig gebruik van veengronden in de Veenkoloniën. De analyse laat ook zien dat de positie van bepaalde stakeholders kan veranderen als de situatie sterk verandert. In een toekomstvariant waarin bijvoorbeeld toerisme een grote rol gaat spelen zal het belang en de invloed van de toeristische sector op de uitkomsten van interventies of projecten toenemen. Bij het uitwerken en implementeren van toekomstvarianten waarin het gebruik van de landbouwgronden in de Veenkoloniën verandert moet rekening worden gehouden met de positie en de belangen van betrokken stakeholders. Door middel van deze stakeholderanalyse kan beter ingeschat worden welke stakeholder op welk moment en op welke manier bij interventies betrokken moet worden.

\subsubsection{Varianten en scoring}

Met de resultaten van de literatuurstudie in het achterhoofd zijn een zestal kansrijke varianten van een agrarisch bedrijf op veen benoemd en vervolgens besproken met experts (zie bijlage 1) Het gaat om de volgende varianten:

- $\quad$ De Water- en energieboerderij

- De Koolstofboerderij

- De Veenproductenboerderij

- $\quad$ De Recreatieboerderij

- De Internetboerderij

- De Circulaire boerderij

De varianten zijn onder andere vormgegeven met de maatregelen die uit de literatuur naar voren zijn gekomen en naar aanleiding van het gebiedsbezoek. De varianten zijn door de onderzoekers benoemd en beschreven m.u.v. de circulaire boerderij die door de experts zesde variant werd benoemd en beschreven. Nadat de varianten verder aangescherpt waren, scoorden de experts de varianten op natuur- en milieukundige aspecten en sociaaleconomische aspecten. Hieronder in Tabel 3 zijn de scores over alle varianten getoond. Deze scores worden daarna per variant besproken. 
Tabel 3. Scores bedrijfsvarianten. Het aantal toegekende scores door de experts is in getallen uitgedrukt (groene 4 betekend dat 4 experts groene score hebben toegekend). Groen=eens, blauw=weet niet/geen impact/niet relevant/neutraal, rood=oneens. De groen gearceerde vlakken betekend dat er 3 of meer groene scores zijn toegekend, een rood gearceerd vlak betekend dat er 3 of meer rode scores zijn toegekend.

\begin{tabular}{|c|c|c|c|c|c|c|}
\hline & $\begin{array}{l}\text { Water } \\
\text { en } \\
\text { energie }\end{array}$ & Koolstof & $\begin{array}{l}\text { Veen- } \\
\text { producten }\end{array}$ & Recreatie & Internet & Circulair \\
\hline \multicolumn{7}{|l|}{$\begin{array}{l}\text { Natuur en } \\
\text { milieukundige aspecten }\end{array}$} \\
\hline $\begin{array}{l}\text { Emissie broeikasgassen } \\
\text { omlaag }\end{array}$ & 13 & 4 & 22 & 212 & 31 & 5 \\
\hline Bodemdaling omlaag & 211 & 13 & 5 & 31 & 311 & 41 \\
\hline $\begin{array}{l}\text { Waterkwaliteit } \\
\text { verbetert }\end{array}$ & 21 & 13 & 2 & 13 & 4 & 22 \\
\hline $\begin{array}{l}\text { Afname water } \\
\text { behoefte }\end{array}$ & 21 & 4 & 4 & 11 & 31 & 11 \\
\hline $\begin{array}{l}\text { Bodemkwaliteit } \\
\text { verbetert }\end{array}$ & 3 & 22 & 13 & 111 & 5 & 4 \\
\hline $\begin{array}{l}\text { Efficiënter gebruik } \\
\text { nutriënten }\end{array}$ & 12 & 21 & 21 & 121 & 5 & 5 \\
\hline Biodiversiteit verbetert & 3 & 4 & 5 & 4 & 31 & 4 \\
\hline \multicolumn{7}{|l|}{$\begin{array}{l}\text { Sociaaleconomische } \\
\text { aspecten }\end{array}$} \\
\hline $\begin{array}{l}\text { Opbrengsten (kg per } \\
\text { ha) omhoog }\end{array}$ & 22 & 4 & 3 & 13 & 5 & 12 \\
\hline Rentabiliteit verbetert & 211 & 13 & 121 & 11 & 121 & 111 \\
\hline $\begin{array}{l}\text { Grotere } \\
\text { multifunctionaliteit } \\
\text { (stabieler inkomen) }\end{array}$ & 4 & 21 & 121 & 41 & 121 & 41 \\
\hline $\begin{array}{l}\text { Hogere investeringen } \\
\text { boer }\end{array}$ & 4 & 121 & 13 & 4 & 3 & 111 \\
\hline $\begin{array}{l}\text { Hogere investeringen } \\
\text { actoren }\end{array}$ & 2 & 21 & 31 & 211 & 111 & 2 \\
\hline $\begin{array}{l}\text { Verbetering } \\
\text { toekomstbestendigheid }\end{array}$ & 4 & 3 & 22 & 22 & 31 & 5 \\
\hline
\end{tabular}

Hieronder presenteren we de varianten en vervolgens bespreken we de door experts toegekende scores. 


\section{De Water- en energieboerderij}

Door klimaatverandering wordt het weer extremer en worden (zeer) droge periodes afgewisseld met (zeer) natte periodes. In droge periodes kan er (te) weinig water worden aangevoerd van elders. De afvoer in natte periodes is nu nog geen probleem. Het waterbergend vermogen van de bodem wordt niet goed genoeg benut op dit moment. De oplossing is waterbuffering in het gebied zelf. Maar waar? Daarvoor is er de Waterboerderij. De Waterboerderij levert blauwe diensten aan het gebied en de ondernemer krijgt daarvoor een vergoeding. Op het agrarisch bedrijf wordt een toch al weggezakte veenput (waar nog een dik veenpakket aanwezig is dat vanwege $\mathrm{CO}_{2}$ emissie behouden moet blijven) omgevormd tot een waterbassin (Figuur 8). Het is ook mogelijk het veen af te graven maar daar zijn de meningen over verdeeld omdat bij het afgegraven veen oxideert. Wellicht zou dit veen gebruikt kunnen worden in potgrond waar nu elders veengebieden voor worden afgegraven.

Op dit bassin komen drijvende zonnepanelen die met de stand van de zon meebewegen om zo optimaal zonlicht in elektriciteit om te kunnen zetten. Daarnaast kan het bassin gebruikt worden voor de kweek van vissen of door recreatieve vissers. Nadeel kan zijn dat de waterkwaliteit verslechtert door voerresten en de uitwerpselen van de vissen. Het bassin moet dan niet in verbinding staan met ander water.

Om te bepalen waar deze variant in het gebied goed zou kunnen passen kun je werken met indicatoren en referentiewaardes specifiek voor deze gronden. Het gaat daarbij om het inschatten van de potentie van de bodem. Met de uitkomst van de indicatoren kun je goed bepalen wat een slechte grond is qua landbouw, en waar deze variant dus goed zou kunnen in de ruimte.

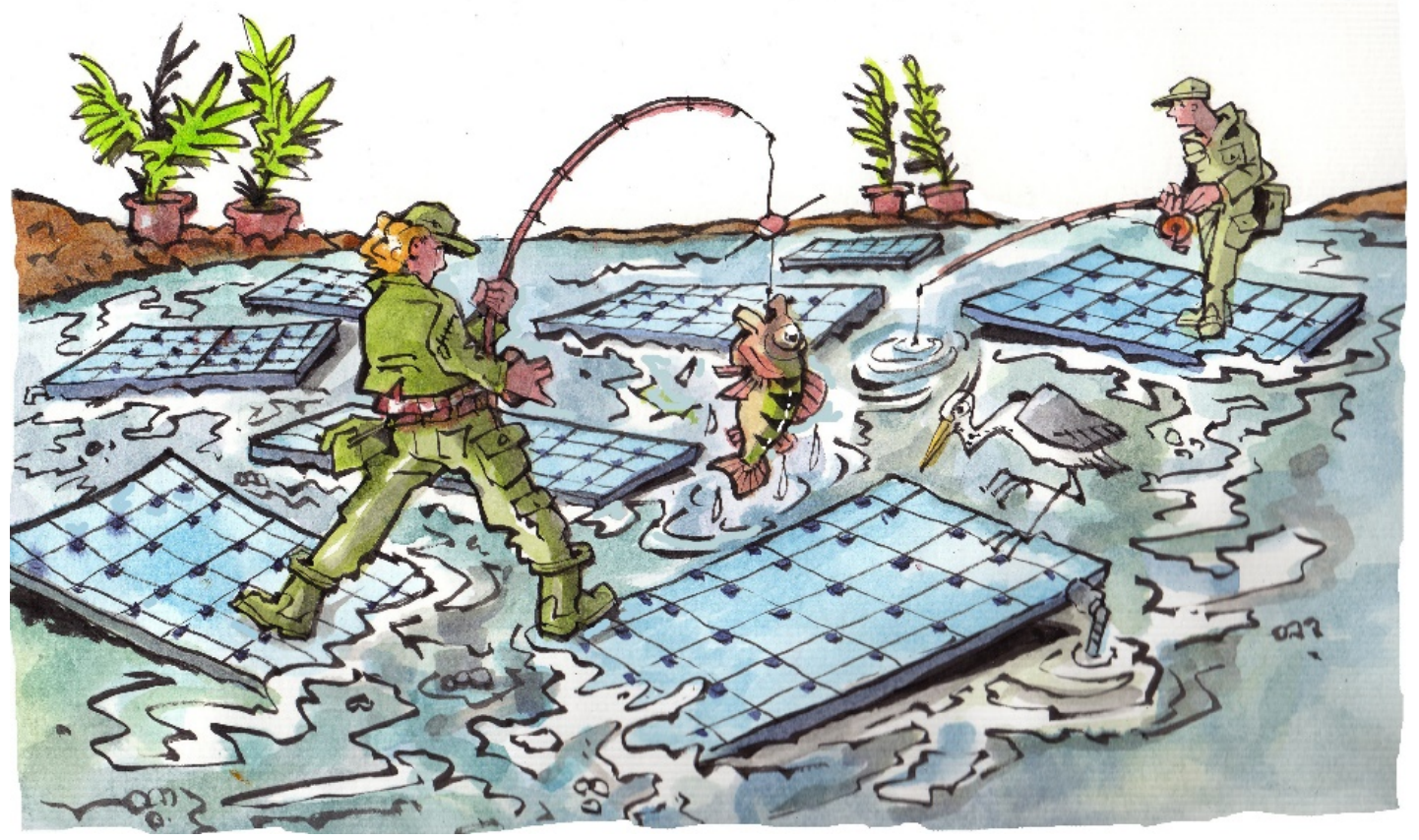

Figuur 8. Impressie-tekeningen van de water- en energieboerderij.

\section{Scores experts}

Een aantal experts meent dat het afgraven van veen een negatief effect kan hebben op de emissie van broeikasgassen. Immers als dat veen verspreid wordt over het land kommen broeikasgassen vrij. Positiever is men over de effecten op de bodemdaling, waterkwaliteit en de biodiversiteit. De meningen zijn verdeeld over het vergroten van de opbrengst per ha en of de rentabiliteit verbetert. Wel verwacht men dat het inkomen van de boer stabieler wordt.

\section{De Koolstofboerderij}

Natuur en landschap staan voorop, landbouw komt op de tweede plaats. Stukken veen komen onder water te staan waardoor het veen niet verder kan oxideren. Op een deel van het bedrijf worden bomen geplant in strokenteelt met eenjarige gewassen (agroforestry), zie Figuur 9. In plaats van dat er $\mathrm{CO}_{2}$ vrij komt wordt er $\mathrm{CO}_{2}$ vastgelegd (Zie ook de factsheet Klimaatcompensatie met agroforestry (WUR, 2019)). De agrarisch ondernemer krijgt een vergoeding voor natuurbeheer en het opslaan van koolstof (dat laatste via een heffing die de overheid oplegt aan bedrijven die veel $\mathrm{CO}_{2}$ uitstoten). 
Wat is de plek van de landbouw hier nog in? Onder water staan betekent dat je in de natte teelten terecht komt zoals cranberries en lisdodde. Dus op goede landbouwgrond is nog akkerbouw mogelijk, verder zet je het onder water. Naast (vrucht)bomen in een agroforestry-systeem kunnen er ook bomen geplant worden in de natte gedeelten van het bedrijf. Denk aan wilgen en elzen, die groeien goed onder natte omstandigheden. Ook groeien deze bomen snel wat zorgt voor een snelle vastlegging van $\mathrm{CO}_{2}$.

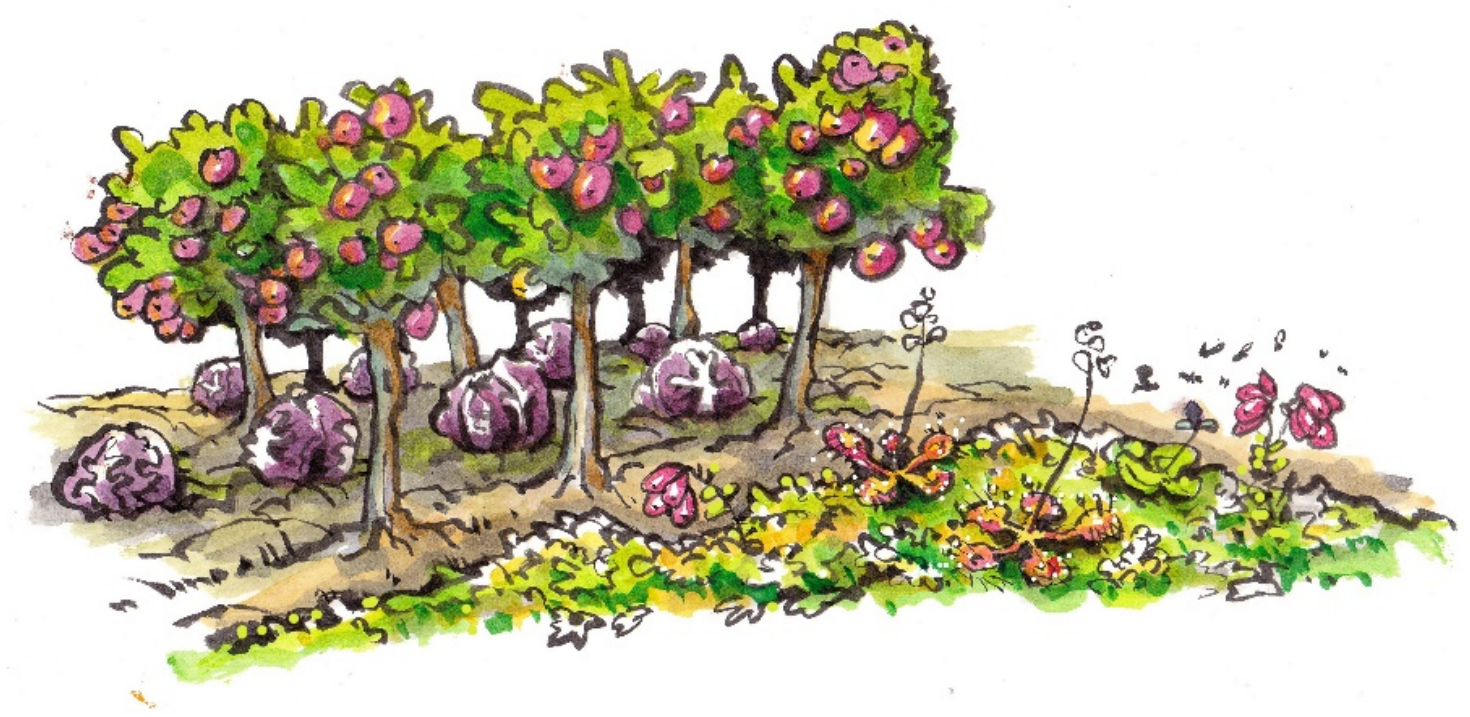

Figuur 9. Impressie-tekeningen van de koolstofboerderij.

\section{Scores experts}

De experts zijn unaniem van mening dat in deze variant de emissie van de broeikasgassen omlaag gaat. Men verwacht wel dat het aanplanten van bomen zorgt voor meer waterverbruik door grotere verdamping. De biodiversiteit verbetert. De opbrengsten per ha gaan omlaag en er is een negatief effect op de rentabiliteit. Deze variant zorgt voor een hogere aantrekkelijkheid van het landschap en daar is in deze regio zeker behoefte aan.

\section{De Veenproductenboerderij}

Er worden alleen nog producten geteeld die geschikt zijn voor (veen)grond, zoals cranberries en lisdodde (Figuur 10). Wellicht wordt een deel van de grond omgezet in blijvend grasland voor de productie van veenweidevlees. De producten worden op de boerderij verwerkt en in de boerderijwinkel verkocht.

De toegevoegde waarde wordt zoveel mogelijk op de boerderij gerealiseerd. Kun je de beperkingen van het gebied omzetten in een verdienmodel waarin je producten teelt die passen bij het gebied en daar mooie producten van produceert met een mooi verhaal (verkoop in bijvoorbeeld Assen, Groningen of combineren met de recreatie boerderij). De ondernemer die dit goed weet te organiseren, kan hier mee aan de slag. Het is een leuke niche, maar voor een beperkt aantal bedrijven. Maar in combinatie met andere varianten kan dit wel een oplossing bieden. Als een ondernemer het niet ziet zitten om zelf deze dieren te houden of veenproducten te telen dan zou hij/zij een samenwerking kunnen aangaan met een ondernemer die dat wel wil gaan doen. Overigens is de teelt cranberries lastig. Met lisdodde worden proeven gedaan. In de eerste jaren vallen de resultaten tegen uit oogpunt van klimaatverandering want er komt veel methaan vrij. Lisdodde wordt geplant op grond die eigenlijk al gedeeltelijk verteert is waardoor er methaan vrij komt en ook lachgas en $\mathrm{CO}_{2}$. Maar op den duur krijg je wel een verbetering. Lisdodde heeft wel nutriënten nodig die je dan in het water aan moet brengen. Een andere oplossing is lisdodde inzetten een soort helofytenfilter. Dat zorgt voor een betere waterkwaliteit en vergroening van het landschap. 


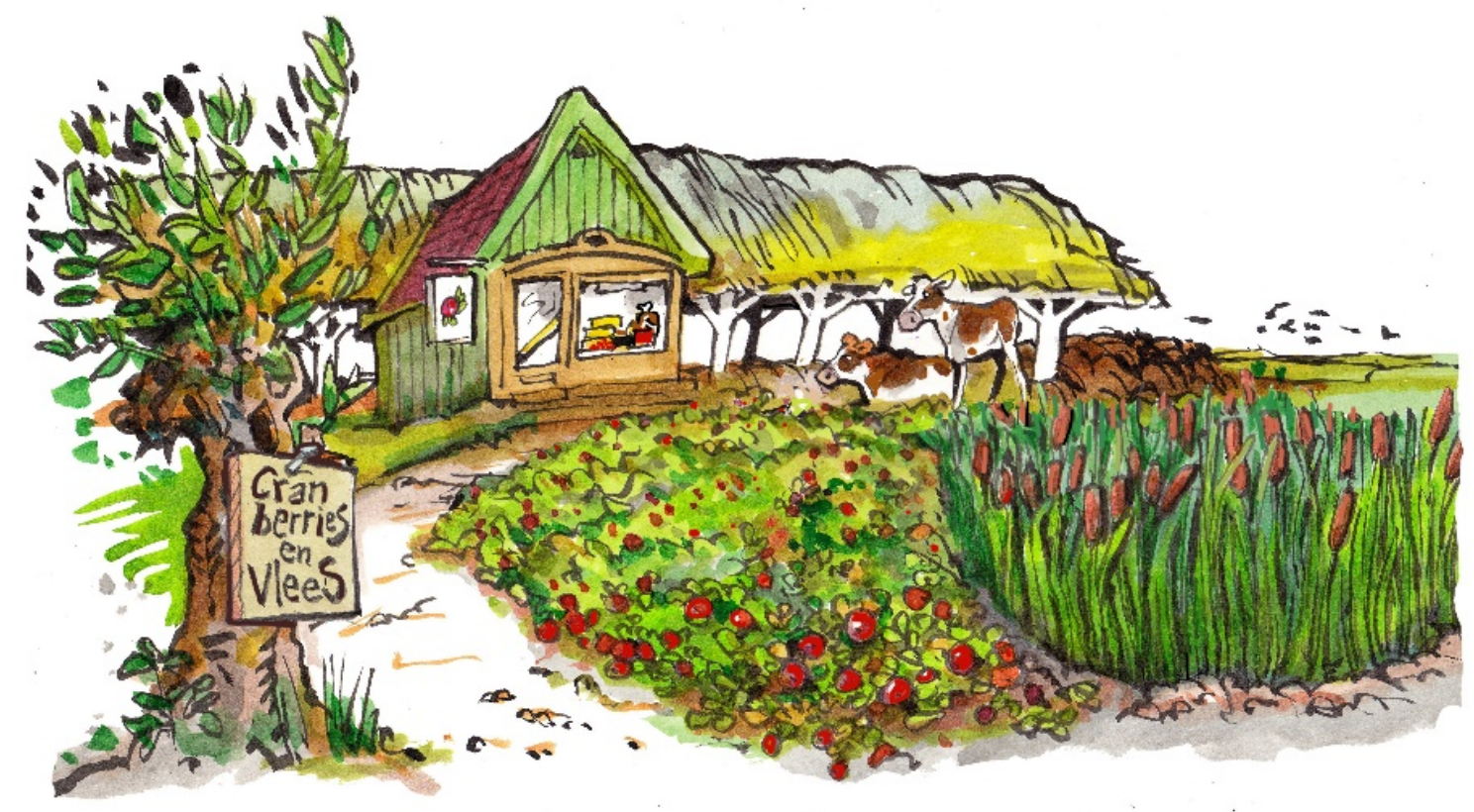

Figuur 10. Impressie-tekeningen van de veenproductenboerderij.

\section{Scores experts}

De experts zijn bij deze variant het meest uitgesproken dat de bodemdaling sterk verminderd wordt. Ook is de verwachting dat de waterkwaliteit en de biodiversiteit verbetert. Het is niet duidelijk wat de gevolgen van deze variant zijn voor de opbrengsten per ha en over een mogelijke verbetering van de rentabiliteit zijn de meningen verdeeld. Ook deze variant zorgt voor een hogere aantrekkelijkheid van het landschap.

\section{De Recreatieboerderij}

Recreatie staat voorop, er komt een pluktuin waar mensen zelf cranberries en bosbessen kunnen plukken en er komt een theetuin en workshopruimte. Daarnaast zijn er allerlei sportieve activiteiten op het land, zoals boerengolf en uiteraard een mud run op de stukken veen (Figuur 11). Natuurlijk kun je er kano's huren om de waterwegen te verkennen. Wellicht ook mogelijkheden om te overnachten. Een mogelijkheid is om dit bedrijf nog verder te verbreden door er zorg bij te betrekken. Dus een zorgboerderij, met een theetuin bijvoorbeeld.

De uitdaging voor dit type bedrijf wordt om gasten te trekken. Dus goed kijken naar de locaties waarop dit kan. Er liggen kansen aan de kant van Westerwolde en aan de kant van de Hondsrug. Daarnaast biedt een goed gebruik van sociale media ook kansen om gasten te krijgen. Als je een goed verdienmodel ontwikkelt dan kun je met een recreatieboerderij zeker een goede boterham verdienen. 


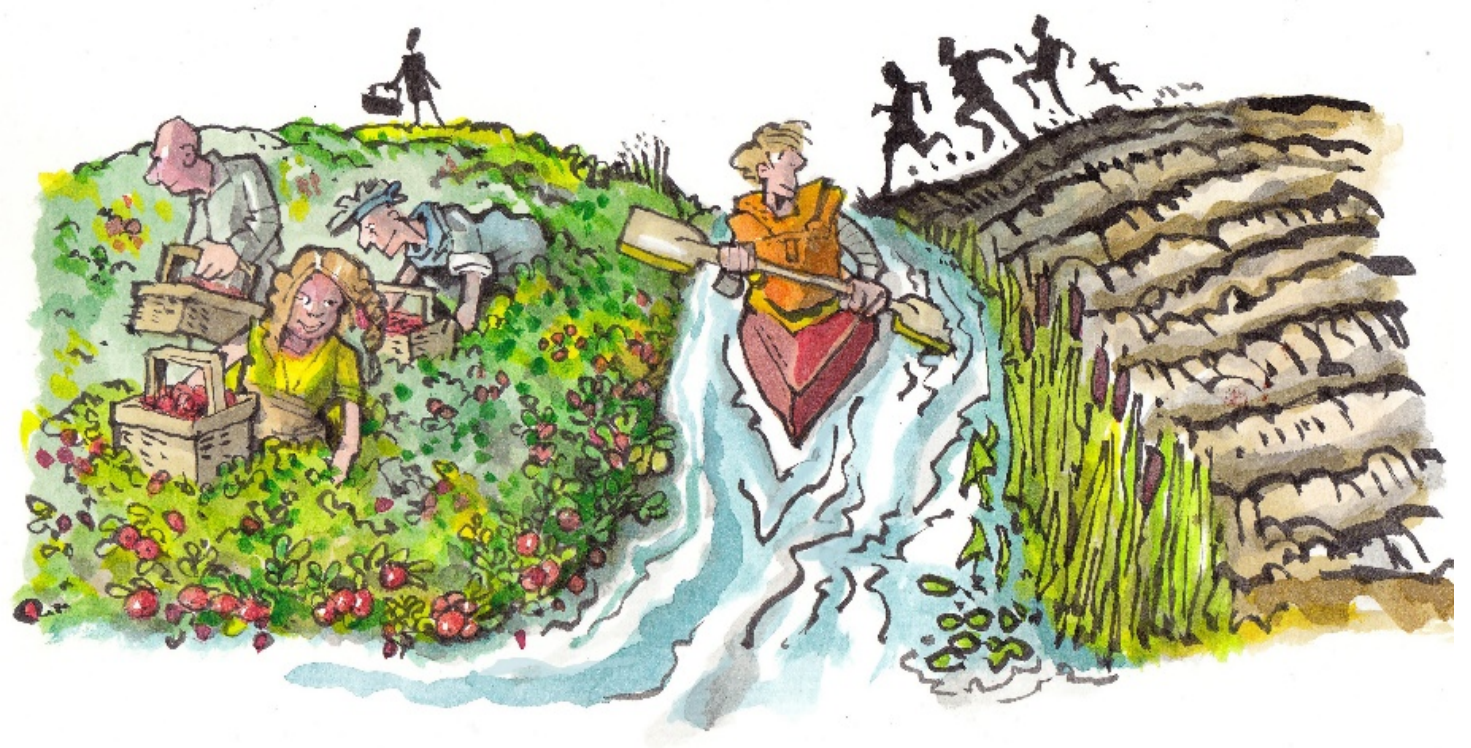

Figuur 11. Impressie-tekening van de recreatieboerderij.

\section{Scores experts}

Of in deze variant de emissie van broeikasgassen omlaag gaat, zijn de meningen verdeeld. Wel denkt men dat de bodem minder zal dalen en de effecten op de waterkwaliteit zijn niet duidelijk. De biodiversiteit verbetert. Men verwacht dat de opbrengsten per ha omlaag gaan maar daar staat een stabieler inkomen tegenover omdat er meerdere inkomstenbronnen aanwezig zijn.

\section{De Internetboerderij}

Met slimme technische oplossingen op het gebied van waterbeheer, grondbewerking en oogsten worden hoge opbrengsten gehaald (Figuur 12). Akkerbouw in de vorm van strokenteelt (verschillende eenjarige gewassen in stroken naast elkaar waardoor er minder gewasbeschermingsmiddelen nodig zijn voor plaag- en ziektebestrijding) waarbij lichte (minder verdichting van de bodem) robots $24 / 7$ het werk doen ondersteunt door drones. Natuurlijk wordt alles continue gemonitord m.b.v. 5G en het 'internet for things'. Sluisjes en onderwater drainage staan via internet voortdurend in contact met Buienradar zodat er snel op voorspelde regen geanticipeerd kan worden. Daardoor kan de waterstand in de sloten langer op een hoger peil blijven.

Het waterschap is hier al mee bezig, anticipeert al op de gegevens die ze krijgen van het KNMI. Dit kan nog verder verfijnd en fijnmaziger gemaakt worden, ook op het boerenbedrijf. 


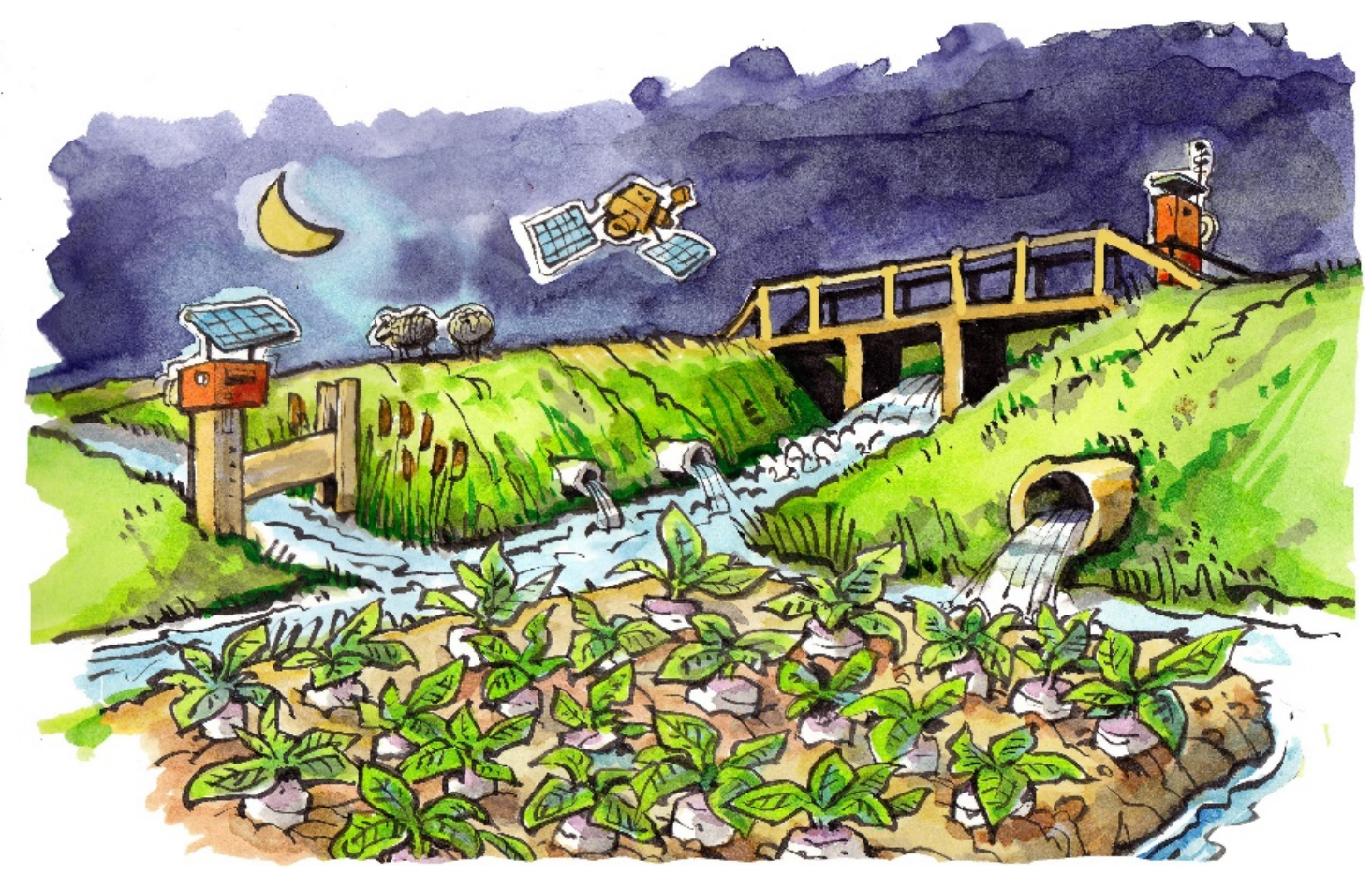

Figuur 12. Impressie-tekening van de internetboerderij.

\section{$\underline{\text { Scores experts }}$}

De meeste experts verwachten dat de broeikasgasemissie in deze variant omlaag gaat. Hetzelfde geldt voor het verminderen van de bodemdaling. Bij deze variant zijn de experts ronduit positief op de effecten voor de waterkwaliteit en -kwantiteit. Ook verbetert de bodemkwaliteit en worden nutriënten beter benut. Bij deze variant is men ook het meest positief dat de opbrengsten per ha zullen stijgen. Dat daarmee ook de rentabiliteit verbetert, is geen uitgemaakte zaak. Wel vraagt het realiseren van deze variant hogere investeringen van de boer.

\section{De Circulaire boerderij}

We begonnen de expertmeeting met vijf varianten. Tijdens de bijeenkomst werd nog een zesde variant benoemd: De Circulaire boerderij (Figuur 13). Dit kan een (traditioneel) gemengd akkerbouw/veehouderij bedrijf zijn maar kan ook een intensieve samenwerking zijn tussen één of meerdere akkerbouw- en veehouderijbedrijven. Dat laatste noemen we ook wel koppelbedrijven. Je kunt dan makkelijker circulair werken.

Op de veenplekken wordt gras geteeld om te voeren aan de koeien en op andere gronden granen en snijmais om het rantsoen te complementeren. De mest van de koeien wordt gebruikt om het gras- en bouwland te bemesten. Doordat er gras geteeld wordt op de veenplekken kan het waterpeil omhoog. 


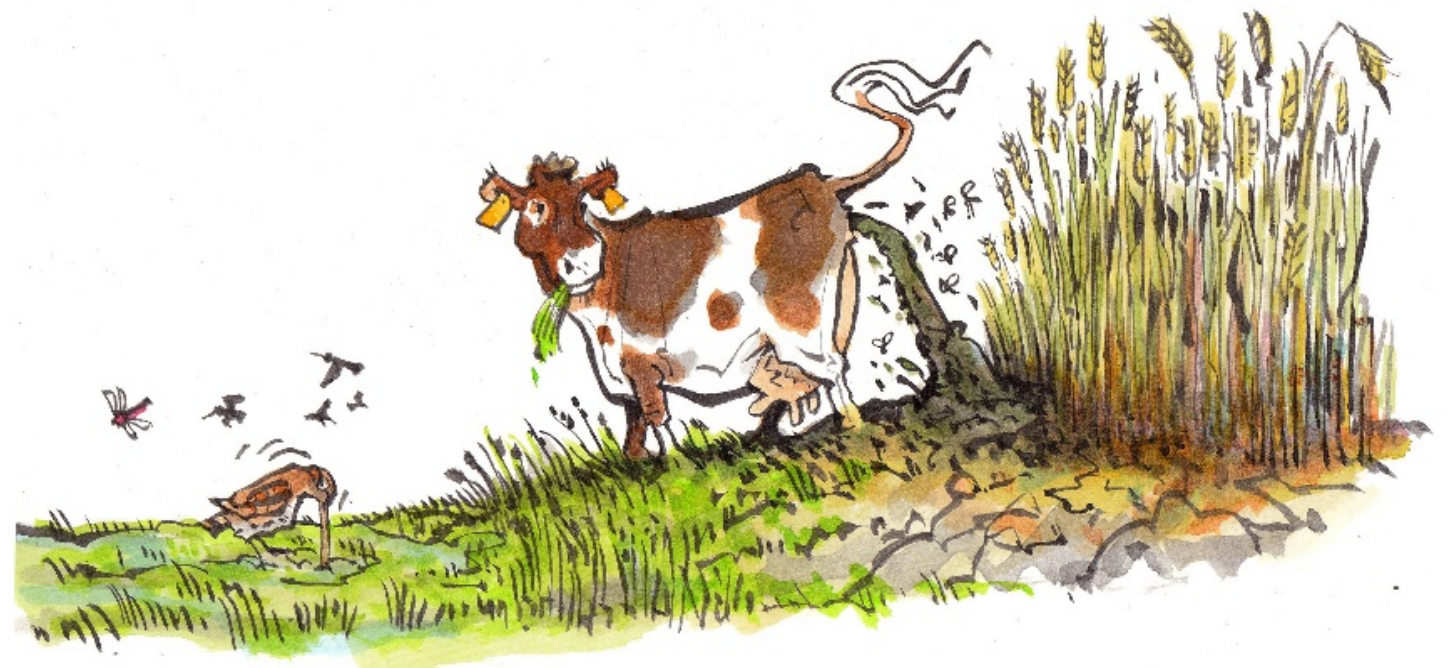

Figuur 13. Impressie-tekening van de circulaire boerderij.

\section{Scores experts}

Bij deze variant zijn de experts het meest uitgesproken dat de emissie van broeikasgassen omlaag gaat. Ook verwachten de meeste experts dat de bodemdaling minder wordt. Ook is men positief over een verbetering van de bodemkwaliteit, een efficiënter gebruik van nutriënten en een verbetering van de biodiversiteit. Het wordt niet helemaal duidelijk wat deze variant doet als het gaat om opbrengsten per ha en de rentabiliteit. Wel verwacht men een stabieler inkomen en een verbetering van de toekomstbestendigheid. Ook is men positief dat deze variant de aantrekkelijkheid van het landschap versterkt.

\section{Algemene opmerkingen bij de scores van de experts}

De scores laten een diffuus beeld zien maar dat is ook niet verwonderlijk. Ten eerste zijn er grote verschillen tussen de varianten onderling en ten tweede zijn de varianten in dit stadium nog niet zover uitgewerkt zodat alle implicaties te overzien zijn. Wel zien we bij alle varianten dat de experts verwachten dat de biodiversiteit verbetert en met uitzondering van de Water- en energieboerderij en de Internetboerderij dat het landschap aantrekkelijker wordt. Men is voorzichtig positief tot zeer positief over het verminderen van de bodemdaling bij de verschillende varianten.

De effecten op de opbrengsten en de rentabiliteit van het bedrijf worden verschillend beoordeeld. Het is duidelijk dat (in een vervolgonderzoek) dit doorgerekend moet worden. Daardoor is ook niet duidelijk wat sommige varianten voor een uitwerking hebben op een stabieler inkomen en of de toekomstbestendigheid van de bedrijven verbeterd wordt.

Het gaat uiteindelijk om een mix van bedrijfsvormen. Dat zorgt ook voor een aantrekkelijker landschap en meer toerisme waardoor 'een sprong over het veen' niet meer nodig is. 


\section{$4 \quad$ Discussie}

Hieronder wordt eerst de aanpak van dit onderzoek kort besproken. Vervolgens worden de resultaten bediscussieerd en in een bredere context geplaatst en gecombineerd in een synthese paragraaf.

\subsection{Aanpak}

In dit project zijn twee benaderingen met elkaar gecombineerd: een literatuurstudie om te verkennen welke oplossingsrichtingen er reeds beschreven zijn in de literatuur en een proces benadering waarin samen met experts mogelijkheden zijn verkend voor veranderend gebruik van veen en moerige gronden voor akkerbouw in de Veenkoloniën. Tevens is in de procesbenadering aandacht besteed aan de mate van belang en invloed van betrokkenen.

De resultaten van de literatuurstudie laten een grote verscheidenheid aan mogelijke oplossingsrichtingen zien. Doordat niet elk onderzoek dezelfde indicatoren heeft gebruikt en elk onderzoek haar eigen focus heeft, kan het lastig zijn om verschillende oplossingsrichtingen met elkaar te vergelijken. Desalniettemin geeft de literatuurstudie een overzicht van mogelijkheden en de oplossingsrichtingen, wat waardevolle input opleverde voor het formuleren van de verschillende boerderij varianten.

Om meer inzicht te krijgen in de mate waarin betrokkenen belang hebben bij en invloed hebben op het doorvoeren van veranderingen, is een stakeholderanalyse gedaan. Echter, in deze fase van het project is alleen samengewerkt met een groep van experts en waterschap, niet met andere direct betrokkenen zoals akkerbouwers of de provincie. Om meer inzicht te krijgen in de belangen van verschillende betrokkenen en oplossingsrichtingen uit te werken die aansluiten bij deze belangen zal in de toekomst ook direct samengewerkt moeten worden met deze belanghebbenden. Hierdoor zal ook meer draagvlak ontstaan voor aangedragen oplossingsrichtingen.

\subsection{Resultaten}

\subsubsection{Toepasbaarheid maatregelen literatuur}

De meeste maatregelen die besproken zijn in 3.1 zijn onderzocht in andere veengebieden in Nederland dan de Veenkoloniën. Een enkele zelfs in het buitenland. Dat betekent dat de effectiviteit van de maatregel niet geheel gelijk hoeft te zijn aan de daadwerkelijke effectiviteit als de maatregel wordt geïmplementeerd in de Veenkoloniën. Daarnaast hebben de maatregelen eisen voor implementatie, die ook de toepasbaarheid van de maatregel bepalen. Zo lijken de natte teelten of de inrichting van (natte) natuurgebieden vooral geschikt op de lage plekken in het gebied, waar vaak de dikke veenpakketten aanwezig zijn. Daarbij hoort dan de combinatie met het compartimenteren van waterpeilvakken, want er moet immers een hoge waterstand gerealiseerd worden voor natte teelten. Nieuwe inrichting van het watersysteem en compartimentering vragen hoge investeringen. Om met deze investering de meeste broeikasgasemissiereductie in de toekomst te realiseren, zijn de dikke veenpakketten meer de moeite waard om te behouden dan de dunnere. Het onderwerken van veen zou een oplossing kunnen zijn voor dunnere veenpakketten en op de moerige gronden. Tevens lijkt, tezamen met het omzetten van akkerbouwland naar grasland, dat een van de weinige oplossingen die realiseerbaar lijkt om de emissies van moerige gronden te reduceren.

De toepasbaarheid van infiltratiedrains in de veenkoloniën is lastig in te schatten. In het veenweidegebied worden zeer positieve resultaten behaald, maar Rozemeijer et al., (2016) vonden minder goede resultaten met peil gestuurde drainage in de Veenkoloniën, omdat de drains verstopt raakten. Helder is wel dat een hogere waterstand veen oxidatie en dus broeikasgasemissie kan 
reduceren. De werking van infiltratiedrains moet verder worden onderzocht en toegepast in de Veenkoloniën om te identificeren op welke plekken het geïmplementeerd kan worden.

De kosten voor maatregelen die emissiereductie van veen en moerige gronden kunnen bewerkstelligen, zouden gecompenseerd kunnen worden door een systeem zoals Valuta voor Veen (Natuur en Milieufederatie Groningen, 2014). Hierin worden emissierechten verkregen door diegene die de emissie van veengronden reduceert. Deze rechten worden verhandeld op een regionale koolstofmarkt. Op deze manier levert de gereduceerde $\mathrm{CO}_{2}$ emissie geld op voor de boer die de maatregel implementeert, waardoor het nemen van maatregelen financieel ook mogelijk wordt. Dit zou ook goed bij de koolstofboerderij toegepast kunnen worden.

\subsubsection{Boerderij varianten}

De boerderij varianten zoals beschreven in het resultatenhoofdstuk, zijn ideaal varianten waarbij elke variant een specifieke, extreme focus heeft. Dit maakt de varianten goede uitgangspunten voor discussie en stelt ook in staat om de varianten met elkaar te vergelijken. Zoals uit de resultaten blijkt, scoren varianten verschillend op de verschillende natuur- en milieukundige aspecten en sociaaleconomische aspecten. Er valt dus niet te zeggen welke variant de 'beste' variant is, maar wel hoe een bepaalde variant op een bepaalde indicator scoort. Hierbij moet de kanttekening geplaatst worden dat deze scoring gedaan is door de experts die bij die project betrokken waren en niet door middel van uitgebreid literatuur of empirisch onderzoek. De scores geven dus alleen een indicatie van het effecten op de verschillende factoren en geven geen absolute en definitieve beoordeling of rangschikking van de verschillende varianten.

Zoals gezegd geven de varianten een ideaalbeeld weer. In de praktijk kunnen varianten uiteraard met elkaar gecombineerd kunnen worden. Ook is niet elke variant geschikt om op grote schaal geïmplementeerd te worden, bijvoorbeeld vanwege een kleine afzetmarkt. Echter, de ideaaltype boerderij varianten geven een goed startpunt voor discussie en voor het initiëren van een exploratie (samen met direct betrokkenen) van mogelijkheden voor veranderend gebruik van veen- en moerige gronden voor akkerbouw, om bij te dragen aan een beperking van $\mathrm{CO}_{2}$ emissies door veenoxidatie.

\subsubsection{Synthese}

Hieronder wordt kort besproken in hoeverre de individuele maatregelen passen binnen de boerderij varianten.

Grasland wordt genoemd als manier om emissies te reduceren. Permanent grasland past goed binnen de circulaire boerderij en de veenproductenboerderij en draagt zowel bij aan een reductie van broeikasgasemissies als aan een meer circulaire systeem. Er moet wel vraag naar de producten van grasland zijn.

De infiltratiedrainage past goed binnen de internet boerderij, waar veel technische oplossingen worden toegepast.

Natte teelten worden toegepast in de veenproducten- en koolstofboerderij. Het idee spreekt aan in het gebied, maar er zijn nog wel vragen rond de teelttechniek en de markt situatie (vraag). Natte teelten scoren bovendien redelijk goed op de duurzaamheidsaspecten. Het gebied moet hier wel op ingericht worden. De Provincie Drenthe is daar inmiddels mee bezig en ziet mogelijkheden. Het waterschap speelt hier ook een rol, omdat er een hoge waterstand (en wellicht compartimentering) gerealiseerd moet worden.

De recreatieboerderij richt zich echt op een niche markt en biedt geen grote potentie voor emissie reductie. Echter, in combinatie met het aanleggen van natte natuurgebieden kan dat wel gerealiseerd worden, waardoor het landschap aantrekkelijker wordt maar de landbouwproductie af zal nemen.

Toekomstgerichte, gevarieerde en klimaatbestendige landbouwbedrijven, zoals hier gepresenteerd, kunnen door niche markten aan te boren of compensaties schema's via het concept Valuta voor Veen te implementeren bijdragen aan het reduceren van de broeikasgasemissies van veen en moerige gronden. 
Het Waterschap Hunze en Aa's heeft gesteld dat dunne veengronden minder prioriteit ontvangen qua behoud in vergelijking met de dikkere veenpakketten, waar nog een flinke emissiereductie en bodemdaling vermindering bereikt kan worden. Dat terwijl de maatregel onderwerken van veen en permanent grasland ook voor minder dikke veenpakketten effectief kan zijn. Dat is echter minder een opgave voor het waterschap en meer één voor de landbouw en de provincie.

\section{Exporteerbaarheid resultaten}

Deze maatregelen en varianten kunnen in principe ook toegepast worden op andere gebieden waar akkerbouw op veen en moerige gronden plaatsvindt. Daar moet wel naar het lokale watersysteem en opgaves gekeken worden. In het gebied van het waterschap Hunze en Aa's is momenteel momentum aanwezig om na te denken over de inrichting van het watersysteem en zouden, met de juiste beslissingen, meerdere doelen gediend worden (klimaatmitigatie, circulariteit). Dat kan echter wel ten koste gaan van het huidige akkerbouwmatig landgebruik. 


\section{Conclusie en aanbevelingen}

Om te komen tot de in het Klimaatakkoord vereiste emissiereductie van veen en moerige gronden, zijn in dit rapport losse maatregelen en boerderij varianten gepresenteerd die daaraan bij kunnen dragen. Helder is geworden dat in het focus gebied de Veenkoloniën maatwerk nodig is, vanwege de ruimtelijk variatie in de dikte van het veen en in de hoogteverschillen die versterkt worden door plaatselijke bodemdaling. In natte, laag liggende gebieden met een dik veenpakket passen de maatregelen natte natuur en natte teelten. Hierbij sluiten de koolstofboerderij en de veenproducten boerderij goed aan. In de andere gebieden met dunnere veenpakketten kan het omzetten naar grasland, onderwerken van veen en de infiltratiedrainage oplossing bieden aan het bereiken van de doelstellingen. De internetboerderij en de circulaire boerderij passen daar goed bij.

In het gebied van het waterschap Hunze en Aa's is momenteel momentum aanwezig om na te denken over de inrichting van het watersysteem en zouden, met de juiste beslissingen, meerdere doelen gediend worden (klimaatmitigatie, klimaatadaptatie circulariteit). Dat kan echter wel ten koste gaan van de huidige akkerbouwmatig landgebruik, zoals ook in de maatregelen en de varianten naar voren komt.

Toekomstgerichte, gevarieerde en klimaatbestendige landbouwbedrijven, zoals hier gepresenteerd, kunnen door niche markten aan te boren, of compensaties schema's via het Valuta voor Veenconcept, bijdragen aan het reduceren van de broeikasgasemissies van veen en moerige gronden.

De maatregelen en varianten vragen om verder onderzoek naar de effectiviteit van de maatregelen en naar de verdienmodellen van de varianten in het gebied. Dit rapport presenteert de uitkomsten van een inventarisatie die gedaan is naar de opties om tot een meer klimaatbestendige landbouw te komen in het Veenkoloniale gebied. In het vervolg project is het van belang dat er gesprekken en werksessies met lokale belanghebbende plaatsvinden om de varianten verder vorm te geven, focus aan te brengen en interesse te wekken voor implementatie bij boeren. Het werkplan 2020 gaat hier verder op in, zie Bijlage 2. 
Bestman, M., Geurts, J., Egas, Y., Houwelingen, K. Van, Lenssinck, F., Koornneef, A., ... Vroom, R. (2019). Natte teelten voor het veenweidengebied.

Dagblad van het Noorden. (2019). Nooit gehoord van Veenoxidatie? Lees dit en je weet meer. Retrieved from https://www.dvhn.nl/extra/Nooit-gehoord-van-bodemdaling-door-veenoxidatie-Lees-dit-en-jeweet-meer-

24214460.html?harvest_referrer=https\%3A\%2F\%2Fwww.google.com\%2Furl\%3Fsa\%3Dt\%26rct\%3Dj \%26q\%3D\%26esrc\%3Ds\%26source\%3Dweb\%26cd\%3D1\%26ved\%3D2ahUKEwjsp7jNzKfkAhUS

de Vries, F., Hendriks, R., Kemmers, R., \& Wolleswinkel, R. (2008). Het veen verdwijnt uit Drenthe Het veen verdwijnt uit Drenthe. Alterra.

de Wolf, P., Klompe, K., Hanegraaf, M., Molendijk, L., \& Vellinga, T. (2018). Verduurzaming samenwerking akkerbouw-veehouderij in Drenthe Verduurzaming samenwerking akkerbouw-veehouderij in Drenthe. https://doi.org/https://doi.org/10.18174/464052

DFID. (2003). Tools for development - A handbook for those engaged in development activity. https://doi.org/10.1080/00358537608453236

Günther, A., Jurasinski, G., Albrecht, K., Gaudig, G., Krebs, M., \& Glatzel, S. (2017). Greenhouse gas balance of an establishing sphagnum culture on a former bog grassland in Germany. Mires and Peat, 20, 1-16. https://doi.org/10.19189/MaP.2015.OMB.210

Hansen, S., Rivedal, S., Øpstad, S., Heggset, S., Deelstra, J., \& Dörsch, P. (2016). GJH emissions and agronomic feasibility for forage production on inverted peat soil, (6630), 4-6.

Havinga, L., \& Perdok, U. D. (1968). Profielwijziging door frezen en mengwoelen.

Hendriks, D. M. D., Van Huissteden, J., Dolman, A. J., \& Van Der Molen, M. K. (2007). The full greenhouse gas balance of an abandoned peat meadow. Biogeosciences, 4(3), 411-424. https://doi.org/10.5194/bg-4-411-2007

Hendriks, R., \& van den Akker, J. J. . (2018). Deltafact Onderwaterdrains.

KTC Zegveld. (n.d.). Onderwaterdrains in het veenweidegebied. Retrieved November 25, 2019, from http://www.ktczegveld.nl/onderwaterdrains-in-het-veenweidegebied/

Kuikman, P. J., Van Den Akker, J. J. H., \& De Vries, F. (2005). Emission of N2O and CO2 rom organic agricultural soils.

Natuur en Milieufederatie Groningen. (2014). Valuta voor Veen, 1-24.

NHI. (2008). Nationaal Hydrologisch Instrumentarium - Deelrapport Bodem, http://www.nhi.nu/. Retrieved from http://www.nhi.nu/

PBL. (2018). Klimaatakkoord Landbouw en landgebruik, 157-194.

Richardson, S. J., Dyer, C. J., \& Jewell, S. N. (1991). Soil mixing in the East Anglian fens. Soil Use and Management, 7(1), 30-33. https://doi.org/10.1111/j.1475-2743.1991.tb00842.x

Rijkswaterstaat. (2017). Bodemdaling. Retrieved from https://www.bodemplus.nl/onderwerpen/bodemondergrond/bodemdaling/

Rozemeijer, J., Hunze, W. S., Klomp, H., Hunze, W. S., \& Ball, S. (2016). Pilot Achterste diep.

Schothorst, C. J., \& Beuving, J. (1968). Het resultaat van een proef met diepploegen van broekveengrond. https://doi.org/10.20759/elsjp.71.2_143

Schrier-Uijl, A. P., Kroon, P. S., Hendriks, D. M. D., Hensen, A., Van Huissteden, J., Berendse, F., \& Veenendaal, E. M. (2014). Agricultural peatlands: Towards a greenhouse gas sink - A synthesis of a Dutch landscape study. Biogeosciences, 11(16), 4559-4576. https://doi.org/10.5194/bg-11-45592014

van de Riet, B., van den Elzen, E., Hogeweg, N., Smolders, F., \& Lamers, L. (2018). Omhoog met het Veen Herstel van een veenvormende veenmosvegetatie op voormalige landbouwgrond in veenweidegebieden.

van den Akker, J. J. ., Kuikman, P. J., de Vries, F., Hoving, I., Pleijter, M., Henriks, R. F. A., ... Kwakernaak, C. (2010). Emission of CO2 from agricultural peat soils in the Netherlands and ways to limit this emission. Alterra, 49, 69-73.

van den Akker, J. J. H., Massop, H. T. L., \& Rietra, R. P. J. J. (2018). Potentiële emissiereductie broeikasgassen Fries veenweidegebied.

Veenweiden Innovatiecentrum. (n.d.). Sturen met Water. Retrieved November 25, 2019, from https://www.veenweiden.nl/services-view/sturen-met-water/

Waterschap Hunze en Aa's. (2017). Bodemdaling door veenoxidatie. Retrieved from https://www.hunzeenaas.nl/werk-in-uitvoering/bvv/Paginas/Het-plan.aspx

WUR. (2016). Klimaatbestendig veenweidegebied - Sturen met Grondwater.

WUR. (2018). Bodemkaart van Nederland.

WUR. (2019). Factsheet Agroforestry - klimaatcompensatie met agroforestry. 


\section{Bijlage 1 Experts aanwezig bij de werksessie}

\begin{tabular}{|l|l|}
\hline Expert & Organisatie en functie \\
\hline Janjo de Haan & WUR, onderzoeker bodem en bemesting \\
\hline Johan Specken & WUR, regio-onderzoeker Valthermond \\
\hline Jan van den Akker & WUR, onderzoeker veen en ondergrondverdichting \\
\hline Marjoleine Hanegraaf & WUR onderzoeker organische stof \\
\hline Wilfried Heijnen & Waterschap Hunze en Aa's, beleidsmedewerker planvorming \\
\hline
\end{tabular}




\section{Bijlage 2 Werkplan 2020}

\section{Werkplan 2020 KB Veengronden Wageningen Plant Research Aanleiding}

Het KB veengronden project richt zich op de opgave die het beheer van veen en moerige gronden hebben om bij te dragen aan een reductie van de uitstoot van broeikasgassen (in $20301 \mathrm{MT} \mathrm{CO}_{2} \mathrm{eq}$. uitstoot reductie) en het meer circulair maken van het huidige landbouw systeem (binnen kringlooplandbouw). Beperken van de veenafbraak, waarbij jaarlijks vele tonnen organische stof verloren gaan met hoge $\mathrm{CO}_{2}$-emissies tot gevolg, zijn daarbij de eerste prioriteit.

In 2019 is door WUR OT, in samenwerking met WEnR, een inventarisatie gedaan op basis van literatuur, gebieds-actoren en experts om alternatieve beheer maatregelen vast te stellen die $\mathrm{CO}_{2}$ emissie van akkerbouw op veen en moerige gronden reduceren, zoals bijvoorbeeld het onderwerken van veen (profiel omkeren/verbetering). Als casus gebied is er gericht op de Veenkoloniën, waar akkerbouw op veen en moerige gronden gebruikelijk is. Alternatieve beheermaatregelen zijn uitgewerkt in boerderij-varianten waarin uiteenlopende toekomstbeelden zijn beschreven en weergegeven in spraakmakende tekeningen. De varianten zijn door experts gescoord op te verwachten prestaties met betrekking tot natuur- en milieukundige aspecten en sociaaleconomische aspecten. Er is tevens een stakeholder analyse gedaan om in beeld te krijgen wie op welke manier bij kan dragen aan duurzamer en meer circulair gebruik van deze gronden in het Veenkoloniale gebied. Het onderwerp veenoxidatie en bodemdaling staat hoog op de agenda bij het Waterschap Hunze en Aa's, vanwege de inrichting van het watersysteem, en aanpassingen daarin. Dat biedt kansen voor onderzoek en duurzame oplossingen.

\section{Vraagstelling}

- Welke varianten zijn geschikt om naar aanleiding van de inventarisatie in 2019 verder uit te werken? En waarom?

- Wat zijn de bijdrages van deze varianten op $\mathrm{CO}_{2}$ reductie en circulariteit?

- Wat zijn de perspectieven (verdienmodellen, maatschappelijke voor- en nadelen) van deze varianten ten opzichte van de huidige situatie?

\section{Aanpak}

Gebruikmakend van de stakeholder analyse uit 2019, wordt samen met belanghebbende (in ieder geval het waterschap Hunze en Aa's vanwege reeds gelegde connecties en interesse) beoordeeld welke varianten verdere uitwerking of aanpassing vragen. Vervolgens volgt een gedetailleerde uitwerking van deze varianten die $\mathrm{CO}_{2}$ emissies van veen en moerige gronden reduceren en bijdragen aan een meer circulaire landbouw. Deze worden besproken en gedeeld in het gebied, waar ook de WUR proefboerderij Valthermond bij wordt betrokken. Dat kan leiden tot interesse en financiering (van bijvoorbeeld provincie, waterschap, of LTO) voor het uitvoeren van experimenten die extra informatie kunnen leveren over losse maatregelen of complete varianten.

\section{Activiteiten}

- Gesprekken met stakeholders om een stap te maken wat betreft het duurzaam gebruik van veen en moerige gronden (om draagvlak en financiering te organiseren).

- $\quad$ Uitwerking varianten die haalbaar zijn en interesse van belanghebbenden hebben.

- $\quad$ Eventueel opzet en aanleg experimenten.

$\circ \quad 0$-meting in eventuele experimenten.

\section{Producten}

- $\quad$ Stakeholder workshop voor draagvlak en interesse.

- $\quad$ Rapport met verdere uitwerking veelbelovende varianten.

- Zo mogelijk, voortgangsrapportage van experimenten met beschrijving opzet, 0 -meting en eerste resultaten van de uitvoering.

\section{Budget 2020}

WPR: $€ 40 \mathrm{k}$ vanuit $\mathrm{KB}$.

We gaan zoeken naar co-financiering voor experimenten door stakeholders. 

Correspondentie adres voor dit rapport:

Postbus 16

6700 AA Wageningen

T 0317480700

www.wur.nl/plant-research

Rapport WPR 825

口,

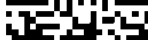

跣
De missie van Wageningen University \& Research is 'To explore the potential of nature to improve the quality of life'. Binnen Wageningen University \& Research bundelen

Wageningen University en gespecialiseerde onderzoeksinstituten van

Stichting Wageningen Research hun krachten om bij te dragen aan de oplossing van

belangrijke vragen in het domein van gezonde voeding en leefomgeving. Met ongeveer 30 vestigingen, 5.000 medewerkers en 10.000

studenten behoort Wageningen University \& Research wereldwijd tot de aansprekende

kennisinstellingen binnen haar domein. De integrale benadering van de vraagstukken en de samenwerking tussen verschillende disciplines vormen het hart van de unieke Wageningen aanpak. 


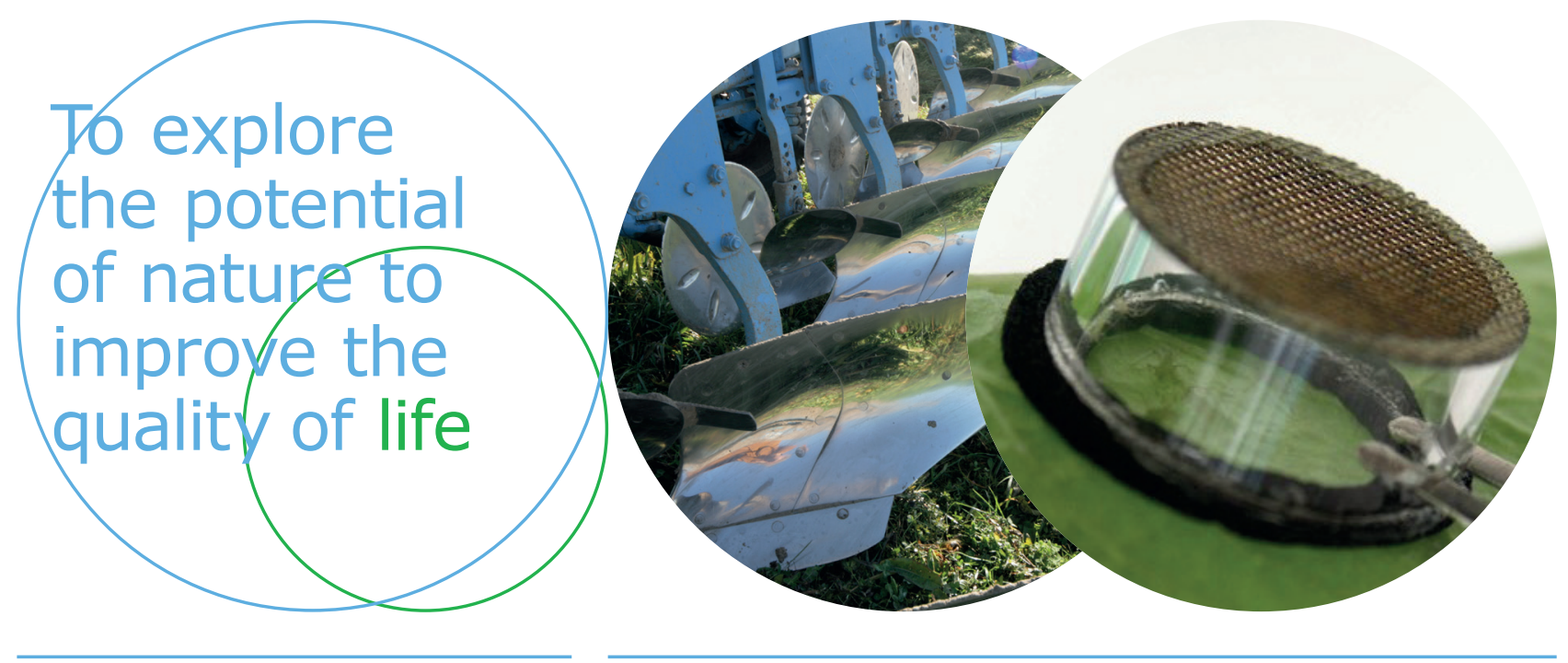

Wageningen University \& Research |Open Teelten Edelhertweg 1

Postbus 430

8200 AK Lelystad

T (+31)320 291111

www.wur.nl/openteelten

De missie van Wageningen UR (University \& Research centre) is 'To explore the potential of nature to improve the quality of life'. Binnen Wageningen UR bundelen 9 gespecialiseerde onderzoeksinstituten van stichting DLO en Wageningen University hun krachten om bij te dragen aan de oplossing van belangrijke vragen in het domein van gezonde voeding en leefomgeving. Met ongeveer 30 vestigingen, 6.000 medewerkers en 9.000 studenten behoort Wageningen UR wereldwijd tot de aansprekende kennisinstellingen binnen haar domein. De integrale benadering van de vraagstukken en de samenwerking tussen verschillende disciplines vormen het

Rapport WPR-825 hart van de unieke Wageningen aanpak. 